\title{
OBITELJSKI ŽIVOT, ODNOSI I VRIJEDNOSTI
}

\author{
Tihana RUBIĆ \\ Filozofski fakultet Sveučilišta u Zagrebu \\ Odsjek za etnologiju i kulturnu antropologiju \\ Ivana Lučića 3, 10000 Zagreb \\ Danijela BIRT \\ Sveučilište u Zadru \\ Odjel za etnologiju i kulturnu antropologiju \\ Ulica dr. F. Tuđmana 24 i, 23000 Zadar
}

\section{„Srodstvo ujedinjava, ono stvara prava i moralne obveze kojih se ne možemo osloboditi“}

(Fortes 1969:242, prema: Segalen 1997:43)

\section{UVOD}

Saku obiteljsku zajednicu, bez obzira na brojnost članova, odlikuje promjenljivost i specifičnost obi$\checkmark$ teljskih okolnosti i ustroja unutarnjih odnosa. Istovremeno, obitelji postoje unutar općih društvenih normi i prihvaćenih simboličkih vrijednosti koje konstruira i podržava lokalna zajednica. Promjenljivost u strukturi obitelji sadržana je prije svega u činjenici da jedan oblik obitelji može u nekom vremenskom periodu biti zamijenjen drugim, kako prirodnim putem (rođenjem ili smrću člana), tako i mijenom unutarnjih odnosa i okolnosti (useljenje, iseljenje, sklapanje braka i dr.).

$\mathrm{Za}$ etnološko istraživanje obitelji zanimljivim se čine upravo različiti transformacijski procesi unutar jedne ili više obitelji, vezani uz emocionalnu privrženost članova, odnose poštivanja i autoriteta, raspodjelu poslova, raspolaganje imovinom, načine organiziranja dnevnih poslova, funkcioniranje obiteljskih okupljanja i sistema uzajamne pomoći, te uz mreže kontakata. ${ }^{1}$ Te se promjene manifestiraju kako na praktičnoj, tako i na vrijednosnoj razini (individualne i kolektivne vrijednosti). One se mogu pratiti dubinski i dijakronijski, u to može biti uključena jedna obitelj, a može se uspoređivati i više obitelji jednu, na jednom, teritorijalno određenom, području (lokalna, regionalna zajednica i dr.). U svom smo se istraživanju odlučili za komparativni pristup.

Istraživanjem je bilo obuhvaćeno nekoliko podtematskih cjelina, koje su se dijelom oslanjale na prijedlog tema iz navedenih upitnica, a za koje smo smatrale da čine etnološki zanimljiv dio obiteljskih odnosa, vrijednosti i praksi, sagledanih kroz kazivanja, sjećanja i interpretaciju lokalnog stanovništva. Naši su sugovornici uglavnom bili starije životne dobi (rođeni dvadesetih i tridesetih godina 20. stoljeća) pa se podaci u ovom prilogu odnose ponajviše na prvu polovicu 20. stoljeća, preciznije, na razdoblje od dvadesetih do sedamdesetih godina. U radu su opisani i interpretirani: rodbinski nazivi, brojnost djece, iseljavanje radno sposobnog stanovništva s područja Krivog Puta u gradove, siromaštvo u prošlosti i implikacije na obiteljski život, rad u kući i izvan kuće, suživot dviju nuklearnih obitelji u jednoj kući, raspodjela obiteljske imovine te potencijalni i ostvareni obiteljski sukobi.

Trodnevno terensko istraživanje obiteljskog života provedeno je tijekom svibnja 2006. godine, na slijedećim lokalitetima: Krivi Put, Žuljevići i Šolići (koji pripadaju naselju Podbilo), Francikovac i Gornji Veljun (koji pripadaju naselju Veljun Primorski), te Pavići, Popići i Katići (koji pripadaju naselju Mrzli Dol). Podaci su prikupljeni putem šire tematske upitnice, sastavljene na temelju pitanja iz Upitnica Etnološkog atlasa (UEA), koja se tiču obiteljskog i društvenog života određenog područja, pod signaturom: Fd 241/ 651 (tema br. 106-110, 112-114). Dio tema pod br. 112-114 u vrijeme pisanja ovog rada nije bio dostupan za pregledavanje. 
Promišljajući o obitelji kao promjenljivoj srodstvenoj, društvenoj i kulturnoj zajednici (Usp. Čapo Žmegač 1998: 16, 256), promjenljivoj ponajprije u pogledu unutarnjih odnosa i brojnosti članova u jednome kućanstvu, istraživanje smo fokusirale manje na formalne: brojnost članova, a više na strukturalne aspekte obiteljskog života: odnose slaganja i sukobljavanja, međugeneracijsku pomoć unutar obitelji i dr. Razlog tako usmjerenog istraživanja je općenit nedostatak etnografskih podataka za ovu temu, odnosno, građe o obitelji i obiteljskim odnosima, a koja se ne dotiče isključivo teme tzv. zadružnih obitelji, već koja je usmjerena na praktičnu i vrijednosnu razinu svih oblika obiteljskog života.

U etnološkoj su literaturi prve i druge polovice 20. stoljeća ${ }^{2} z a d r u g e^{3}$ bile isključivim fokusom istraživanja. One su se time hipostazirale spram ostalih oblika obiteljskog života. Promatrane su bile u primarno dvama značenjima ${ }^{4}$ : velika obitelj (pritom imajući na umu srodničku, krvnu pripadnost članova) i veliko kućanstvo (kad je riječ o nesrodničkim odnosima unutar kućanstva) (Čapo 1998: 253). U domaćoj etnologiji s kraja devedesetih godina 20. stoljeća, Jasna Čapo Žmegač najcjelovitije i kritički raspravlja o strukturi i funkciji tzv. zadruge, te je poima prije kao veliko kućanstvo, nego kao veliku obitelj", “jer njezino dinstiktivno obilježje (spram nuklearnih obitelji, op.a.) zapravo je zajedničko vlasništvo” (Ibid.), a ne nužno srodnički odnos ili velika brojnost članova. Autorica se kritički osvrće na činjenicu da su dotadašnja etnološka istraživanja obitelji ${ }^{6}$ usmjerena na razdoblje od kraja 19. i prvu polovicu 20. stoljeća, bila fokusirana na zadruge, premda su (što je razvidno iz statističkih, kvantitativnih analiza) nuklearne obitelji u Hrvatskoj, u tom istraživanom razdoblju, prevladavale. ${ }^{7}$ Ista autorica je (1998) također upozorila na činjenicu kako u etnografskim izvorima iz 20. stoljeća "pretežu opisi velikih obitelji i kućanstava s više bračnih parova, tzv. zadruga», te "izostaju opisi života u malim obiteljima koje su već početkom 20. stoljeća dominirale na širokom hrvatskom području» ${ }^{8}$ (253). Time se dobiva pogrešna predodžba o tipu i brojnosti

2 Vidi, primjerice: Seljačke obiteljske zadruge, Izvorna grada za 19. i 20. st. (1960.), Svezak 1 i Seljačke obiteljske zadruge, Izvorna građa za 19. i 20. st. (1992.), Svezak 2, Etnološki zavod Odsjeka za etnologiju Filozofskog fakulteta Sveučilišta u Zagrebu.

3 U etnološkoj literaturi nailazimo na složenicu seljačke obiteljske zadruge (Gavazzi et. al. 1960, 1992); u povijesnoj i pravnoj literaturi korišten je termin kućne zadruge (Pavličević 1989; Utješenović Ostrožinski 1988.), U pravnoj je litaraturi taj pojam različit u svom značenju spram seljačkih radnih zadruga, odnosno poslijeratnog socijalističkog radnog, poloprivrednog udruživanja (zadrugarstva).

4 Razliku između mogućih srodničkih, kao i nesrodničkih veza, unutar jednog kućanstva, u osvrtu na stariju literaturu, najjasnije je istaknuo francuski sociolog Emile Sicard (1974). Njegov rad (izvornog naslova: Problème familiaux chez les Slaves $d u$ sud) je domaćim znanstvenim krugovima najcjelovitije predstavila Dunja Rihtman Auguštin u knjizi Struktura tradicijskog mišljenja (1984.). D. Rihtman Auguštin (1984.) je ukazala na značaj tumačenja strukture zadruge E. Sicarda kao zajednice "po krvi ili srodstvu, po radu, životu i autoritetu“, naglasivši značajku autoriteta ,starješina $i$ njegova prava upravljanja i raspolaganja imovinom" (Sicard 1974: 30, prema: Rihtman-Auguštin 1984:179), ali i višesmjernost odnosa autoriteta u zadruzi, a zadrugu je istovremeno označio i kao ekonomsku zajednicu (zajednički rad i život te mogući nesrodnički odnosi unutar nje). Značaj teksta E. Sicarda o zadrugama, prema D. Rihtman Auguštin, izniman je u teorijskom smislu usustavljenja višeslojnog modela raznih odnosa autoriteta unutar zadruge (RihtmanAuguštin 1984:180). Kasnije, u kritičkim osvrtima na ranija istraživanja i pisanja o obitelji, Jasna Čapo Žmegač govori o obiteljskoj i srodničkoj zajednici kakva se u starijoj etnološkoj literaturi označavala terminom zadruga, namjerno koristi termin kućanstvo umjesto zadruga, što obrazlaže u poglavljima o seoskom društvenom i obiteljskom životu (Čapo Žmegač 1998: 271-284)

5 Vidi spomenuti tematski prilog: Ibid.

6 Primjerice, sredinom 20. stoljeća objavljena je većina samostalnih tekstova Milovana Gavazzija, nastalih tijekom prve polovice 20. stoljeća u kojima je M. Gavazzi, između ostalog, pokušao protumačiti porijeklo južnoslavenskih zadruga, osvrtao se (1978.) na problematiku zadruge u širem europskom društvenopovijesnom kontekstu, te na pojedinačne tradicijske djelatnosti u okviru zadruga. Početkom druge polovice 20. stoljeća (1960.) objavljena je, nadalje, pod uredništvom M. Gavazzija, publikacija Seljačke obiteljske zadruge I (Izvorna grada za 19. i 20. stoljeće).

Čapo 1998: 254.

8 J. Čapo Žmegač upozorava da i «zato što su etnolozi tragali samo za velikim kućanstvima, nastao je manjak, gotovo (...) apsolutni nedostatak za sva hrvatska područja opisa života malih obitelji, a u jadranskoj zoni obitelji općenito.» (Ibid.) 
kućanstava u Hrvatskoj na prijelazu stoljeća, a tu tvrdnju autorica potkrepljuje statističkim podacima za zadnja desetljeća 19. stoljeća. (Čapo Žmegač 2001:498)

U dosadašnjim radovima nastalim u okviru spomenutoga znanstvenog projekta, a objavljenima u Senjskom zborniku (1999, 2000, 2003, 2004)9 , koji se tiču niza tema iz tradicijskog života Krivopućana, na više je mjesta ukazano na nedostatak ranijih etnoloških istraživanja na tom zemljopisnom i kuturnom području, te općenito na nedostatak etnografske građe ${ }^{10}$. Etnološki radovi Milane Černelić, voditeljice Projekta, dijelom nastali i temeljem ranijih ${ }^{11}$ vlastitih terenskih istraživanja na području Like i Primorja, rijetki su ciljani etnološki radovi o obiteljskom životu nekog hrvatskog regionalnog područja.

U radovima se autorica bavi primjerima zadruga koje istražuje prema sjećanjima posljednjih živućih članova zadružne obitelji, rođenih početkom 20. stoljeća, a sjećanja se odnose na prvu polovicu 20. stoljeća. S obzirom na neuobičajeno dugu opstojnost unutarnjih zadružnih odnosa u tim obiteljima ${ }^{12}$, ti su kazivači imali vlastito iskustvo življenja i privređivanja u obiteljskoj zadruzi. Etnografskim opisima i etnološkoj interpretaciji M. Černelić ne možemo prigovoriti na generalizaciji: zadrugu Rukavina-Jauci iz Smiljanskog Polja blizu Gospića autorica bilježi kao primjer neuobičajeno duge opstojnosti zadruge (sve do kraja 20. stoljeća), te ukazuje na unutarnje promjene u brojnosti članova unutar te zadruge tijekom 20. stoljeća. M. Černelić toj zadruzi pristupa kao studiji slučaja (case-study), a u opisima i interpretaciji odmiče se od generalizacija za cijelo regionalno područje. $S$ tim u svezi, ističe promjenljivost prilika i razvojnih faza svakog konkretnog slučaja te upozorava na važnost istraživanja pojedinačnih slučajeva na jednom regionalnom području, te kako za općenitiji komparativni prikaz više zadruga trenutno ne postoji dovoljan uzorak pojedinačnih etnološki istraženih zadruga u Lici ${ }^{13}$.

Ipak, nažalost, niti tim etnološkim istraživanjima na području Like nisu obuhvaćene nuklearne obitelji; točnije, one koje nisu poznavale radnu i hijerarhijsku strukturu zadružnog života ${ }^{14}$, a koje su i na tom području (kao i u ostalim dijelovima Hrvatske) bile znatno brojnije ${ }^{15}$. Dakle, do danas ne možemo reći kako raspolažemo cjelovitom slikom obiteljskih odnosa u prošlosti Krivoga Puta.

Naposljetku, u prilozima obaju svezaka Monografije, često konzultiran izvor - Upitnice etnološkog Atlasa (UEA), za ovu nam temu također pokazuje ograničenosti. UEA ${ }^{16}$ obuhvaćaju teme u kojima se prepliću pitanja vezana uz društvene i obiteljske odnose u tematskim cjelinama poput one br. 106. Vrste zadruga, osobina, dioba; 107. Rodaci i njihovo oslovljavanje; 108. Nekrvno srodstvo; 109. Selo kao zajednica; 110. Glavni oblici zajedničkog rada; 112. Podjela poslova po spolu; 113. Ženske svečanosti i povlastice; te 114: Znakovi vlasništva i zabrane. Međutim, nema šire koncipiranih tematskih pitanja o obiteljskim

Vidi radove Milane Černelić objavljene u Senjskom zborniku 26 (1999.), 27 (2000.) i 30 (2003.), te: Danijele Birt, Jasmine Jurković, Petre Kelemen, Marije Kulišić i Ivane Vuković, Marijete Rajković i Tihane Rubić u Senjskom zborniku 31 (2004.).

10 Neke od tema koje se dotiču materijalne, društvene i duhovne kulture prvi put su, na području Krivoga Puta, istraživane u okviru spomenutoga znanstvenog projekta.

11 Istraživanja provedena osamdesetih godina 20. stoljeća. Više o tome dalje u prilogu.

12 Autorica navodi kako je u vrijeme ispitivanja (1981. godine) zadruga bila na okupu, a da je tako i ostala idućih desetak godina nakon provedenog istraživanja (Černelić 1999:298).

13 Ibid.

14 Vidi više o tome dalje u tekstu, u odlomku naslova Suživot dviju nuklearnih obitelji (dvojica braće sa ženom $i$ djecom) u istoj kući.

15 J. Čapo Žmegač je, donoseći opći pregled povijesnih i tradicijskih okolnosti, te etnološki zanimljivih značajki obitelji kao segmenta hrvatske seoske društvenosti, istaknula kako su: „početkom 20. stoljeća kućanstva u Hrvatskoj (...) u svim regionalnim područjima u prosjeku bila mala" (1998: 254). Stoga.fokusiranje na zadružni oblik obiteljskog života, kao isključivi predmet dosadašnjih etnoloških istraživanja, predstavlja „značajni nedostatak u dosadašnjim pristupima $i$ gradi kojom raspolažemo" (ibid.)

16 Pohranjene u Arhivu Odsjeka za etnologiju i kulturnu antropologiju Filozofskog fakulteta Sveučilišta u Zagrebu. 
odnosima, praksama i vrijednostima, koji bi za cilj imali sveobuhvatnije istraživanje ove teme. Pitanja koja su predložena u okviru UEA treba, međutim, generalno shvatiti tek kao polazište u istraživanju, jer obuhvaćaju osnovna pitanja na temelju kojih svaki istraživač treba, u proširenom obliku, prilagoditi upitnicu datom kulturnom i regionalnom području koje istražuje. Kritiku UEA, kao mogućeg izvora za etnološko istraživanje, već su donijeli neki od autora priloga u prvom svesku Monografije (Rubić 2008: 324; Rajković 2008: 267). Ovdje ćemo se kratko osvrnuti na nekoliko konkretnih napomena vezanih uz etnološko istraživanje teme obiteljskog života. Upitnicom za temu br. 106, šezdesetih se godina 20. stoljeća, u naselju Krivi Put ispitivalo o vrstama zadruga, osobinama i diobama. Iako smatramo problematičnim postavljanje pitanja Krivopućanima o zadruzi jer je termin nije lokalno upotrebljavani naziv za tip proširene obitelji, već predstavlja znanstvenu konstrukciju, u značenju velikih kućanstava sastavljenih od više nuklearnih obitelji, a razlikovni element spram nuklearnih obitelji je ponajprije zajedničko vlasništvo (Čapo Žmegač 2001:498). Termin zadruga unatoč tome koristi se i u Upitnici Etnološkog atalasa, koja sadržava podatke za naselje Krivi Put ${ }^{17}$. Ipak, uočljivo je (prema sadržaju upisanih odgovora) kako je kazivač precizno odgovarao na pitanja o diobi zadruge, po čemu se zaključuje da je uglavnom razumio da se pitanje istraživača odnosilo na oblik većeg broja ukućana i zajedničkoga vlasništva, te se čini i kako je govorio o njemu poznatim slučajevima dioba. Tema br. 107. Rođaci i njihovo oslovljavanje donosi nam niz odgovora na pitanje o rodbinskom oslovljavanju pobrojavanjem rodbinskih naziva. Ipak, ostaje nejasan kontekst oslovljavanja, kao i promjene u oslovljavanju i rodbinskim nazivima koje su se tijekom vremena zasigurno odvijale. Istaknule bismo dvije teme: br. 108. Nekrvno srodstvo i br. 110. Glavni oblici zajedničkog rada. Obje naznačuju značaj ostalih oblika društvenih odnosa, pored srodstvenih, u svakodnevnom životu. Te teme u okviru ovog priloga nisu obrađene, jer bi zahtjevale cjelovitije i ciljano, zasebno, istraživanje, što uvelike premašuje dosege ovog priloga; riječ je o susjedskim i prijateljskim odnosima, koje možemo promatrati kao neizostavan aspekt istraživanja društvenosti u svakodnevnom životu pojedinaca. Na pitanje: Ima li čovjek u drugom kraju prijatelja s kojim se doduše rijetko vida, ali kod kojega uvijek odsjeda kad dođe u o mjesto (prijatelj, ortak, ili?), odgovoreno je: U mjestu gdje se često odlazi poslom čovjek stekne i dobroga prijatelja. Iz ovog je odgovora razvidno kako je stjecanje prijateljstava u mjestu rada, različitom od onog u kojem se živi, moglo biti uobičajena pojava. Jasno nam je i kako spomenute okolnosti stjecanja prijateljstva pripadaju ponajprije dijelu muškog življenog iskustva, jer je poznato kako su uglavnom muškarci izbivali od kuće na kraće ili duže vrijeme radi posla u šumi i sl. ${ }^{18}$ pa nam ostaje nepoznato na koji način su obrasci prijateljstva i sklapanja prijateljstava na području Krivoga Puta, u prošlosti i danas, rodno određeni i različiti. Uglavnom, niti ovim odgovorom ne doznajemo mnogo o konkretnim iskustvima i intenzitetima prijateljevanja, ali nam odgovor naznačuje kako je vrednovano kao osobni kapital u kontekstu fizičkog rada i izbivanja iz vlastite društvene zajednice. Tema br. 110. uključuje pitanja o glavnim oblicima zajedničkoga rada, sa i bez formalnog udruživanja. Zanimljiva su nam dva odgovora: Uobičajeni način (zajedničkoga rada, op.a.) je da pomažu jedni drugima od prigode do prigode. Ne saznajemo iz ovoga preciznije tko pomaže. U idućem odgovoru saznajemo koje su to bile prigode (žetva, kosidba, sadnja krumpira, gradnja kuće). Ipak, primjećujemo kako je međusobno pomaganje vrednovano kao normalitet, a (na trećoj stranici upitnice za ovu temu) pojavljuje se i izjava kojom se precizira tko pomaže: Uobičajeno je da susjedi jedni drugima pomažu. Ističemo u svezi s tim kako susjedstvo i susjedski odnosi jedna je od tema koja također zahtjeva ciljana istraživanja, kao još uvijek neistražen aspekt društvenih odnosa na području Krivoga Puta, a koju također nismo obuhvatili ovim prilogom.

Ciljanom etnografskom istraživanju obitelji, obiteljskih i rodbinskih odnosa, praksi i vrijednosti, kao aspektu društvenog života i odnosa na području Krivoga Puta, pristupilo se 2006. godine u okviru znan-

17 Zapisivač: Slobodan Šimić; kazivač: Milan Krmpotić.

18 Vidi više u nastavku ovog priloga. 
stvenog projekta Identitet i etnogeneza primorskih Bunjevaca, voditeljice dr. sc. Milane Černelić. ${ }^{19}$ Istraživanjem je bilo obuhvaćeno nekoliko podtematskih cjelina, bez unaprijed zadanog i hipostaziranog oblika obiteljskog života. Ispitivane su sljedeće teme: rodbinski nazivi, broj rođene djece, utjecaj siromaštva na obiteljski život i dr. Sve navedeno predstavlja tek jedan segment mogućih tematskih jedinica koje mogu biti fokusom etnološkog istraživanja na jednom zemljopisnom i kulturnom području.

Već je Dunja Rihtman (1967.) upozorila na značaj istraživanja kolektivnih i individualnih vrijednosti u zajednici ${ }^{20}$, kao mogućeg istraživačkog i interpretacijskog pristupa, za koji je etnologija dosad nedovoljno bila korištena. Vodeći se tim prijedlozima nastojalo se, u okviru ovog priloga, kvalitativno interpretirati vrijednosnu razinu obiteljskih odnosa i života, u sprezi s praktičnom razinom življenja na području Krivoga Puta u 20. stoljeću, do sedamdesetih godina. ${ }^{21}$ Zašto se u radu fokusiramo na to razdoblje? Sjećanja



Slika : Obitelj Juraja Prpića iz Krivog Puta, 1962. (foto Arbiv GMS)

19 Tekst je, u znatno izmijenjenom obliku, prethodno objavljen u Senjskom zborniku: Birt, Danijela, Rubić, Tihana (2006.): Obiteljski život na području Krivog Puta od tridesetih godina 20. stoljeća do danas. Etnografski prilog i prijedlozi za buduća istraživanja, Senj: 3. Rad predstavlja rezultat jednokratnog istraživanja obiteljskih odnosa na području Krivoga Puta. Temeljen je na propitivanju iskustava i vrijednosti, koje su imenovani sugovornici iskazivali na temelju priča iz vlastita djetinjstva (prije Drugog svjetskog rata) ili putem prisjećanja na događaje kojih su bili nosioci ili suvremenici (nakon Drugog svjetskog rata do sedamdesetih godina 20. stoljeća). Iskaze sugovornika na više mjesta citiramo, a sugovornike navodimo poimence u samom tekstu (u bilješkama). U svrhu ovog istraživanja ispitani su nama poznati, „razgovorljivi“ kazivači, s kojima je dosad uspostavljen blizak istraživački odnos (na području Krivoga Puta istraživački tim, pod vodstvom M. Černelić, istražuje od 2003. godine). Navođenje generalija kazivači tada nisu smatrali problematičnim, te su ih često isticali, ǐ̌čekujući objavu imena i rezultata istraživanja u Senjskom zborniku. Detaljizirani pregled ispitanih osoba može biti orijentirom za neka daljnja terenska istraživanja na tom području, jer rad sadržava niz podataka o kazivačima: ime i prezime, špic-namet (nadimak), djevojačko prezime, godinu i mjesto rođenja, te mjesto stanovanja. Navođenje podataka o kazivačima predstavlja praksu nastavljenu iz dosadašnjeg istraživačkog postupka i produkcije znanstvenih radova unutar znanstvenog projekta Identitet i etnogeneza primorskih Bunjevaca. S obzirom da je riječ o višegodišnjem istraživanju, s kazivačima je uspostavljen blizak odnos, a većina ih je, u svrhu intervjuiranja, posjećena višse puta i upitana o različitim temama iz tradicijske kulture krivoputskog područja. Tom prilikom kazivači su bili upitani i za generalije.

20 Svoje je prijedloge u radu iz 1967. godine Dunja Rihtman primijenila na primjerima radne zajednice (radni kolektiv unutar poduzeća), no prijedlozi se odnose i na proučavanja na bilo kojoj drugoj tematskoj i društvenoj razini (Rihtman 1967).

21 Propitivanje obiteljskog života i odnosa u narednim bi istraživanjima trebalo individualizirati, u svrhu saznavanja različitosti pojedinačnih obiteljskih prilika, odstupanja od društvenih simboličkih vrijednosti, koje se, u okviru specifičnih 
naših sugovornika koji su 2006. godine pripadali najstarijoj živućoj generaciji (oni rođeni dvadesetih i tridesetih godina 20. stoljeća) sežu unatrag uglavnom na međuratno razdoblje, odnosno prvu polovicu 20. stoljeća. Sedamdesete godine 20. stoljeća, s druge strane, prepoznate su našim terenskim istraživanjima kao godine koje i sami kazivači percipiraju kao izrazit rez i prekid s dotadašnjim, dominantno "tradicijskim” (ručna proizvodnja, slabija dinamika pokretljivosti unutar užeg i šireg regionalnog područja, nepostojanje automobilskog prijevoza, predindustrijsko razdoblje, i dr.) načinom života.

\section{POIMANJE OBITELJII2}

$\mathrm{P}$ rimjećujemo kako razgraničenja i interpretacije korištenih pojmova koji se tiču obitelji i obiteljskih odnosa (primjerice, obitelj, proširena ${ }^{23}$ i nuklearna ${ }^{24}$ obitelj i sl.), predstavljaju nužan, sustavniji dio budućeg etnološkog bavljenja temom obitelji. ${ }^{25}$

Tijekom 20. stoljeća, prosječan broj članova unutar jedne stambene jedinice - kućanstva, varirao je ponajprije s obzirom na broj djece u kućanstvu. Iznosio je u prosjeku šest do sedam. ${ }^{26} \mathrm{Uz}$ to, nuklearna je obitelj (oženjeni sin sa suprugom i djecom) živjela u kući roditelja, tako da je u jednom kućanstvu paralelno živjelo jedno ili dvoje pripadnika starije generacije. ${ }^{27}$

$\mathrm{Na}$ taj način kazivači najčešće i određuju pojam obitelj i uža obitelj - kao zajednicu triju generacija unutar jednog kućanstva. Danas obitelj u jednom kućanstvu čini najčešće roditeljski par s djecom, bez pripadnika starije generacije. Ipak, i danas ponegdje u jednoj obiteljskoj kući stanuje dvije ili više nuklearnih obitelji. Najčešće je taj suživot barem djelomično prostorno razgraničen - svaka nuklearna obitelj na zasebnom katu. ${ }^{28}$ Nerijetko u istoj kući žive i jedan ili dva pripadnika starije generacije (roditelji), najčešće također u djelomično odvojenom dijelu kuće ${ }^{29}$. Dakle, možemo reći da je općenito uočena tendencija uspostavljanja stambene autonomnosti nuklearnih obitelji zasebno, uspostavljanjem više malih prostornih jedinica (zasebnih kućanstava) u jednoj kući. ${ }^{30}$

Ipak, odgovori na pitanje o razlikovanju uže od dalje obitelji, međusobno se razlikuju i u čvrstoj su vezi s različitim individualnim iskustvima, kao is različitim obiteljskim odnosima i, unutar obitelji naučenim, vrijednostima.

Pojmove obitelj i rodbina kazivači vrlo često koriste kao sinonime, a u značenju šire mreže krvno ili ženidbeno povezanih srodnika. Nerijetko njima ipak razlikuju obitelj kao zajednica u užem (emocionalna bliskost, stanovanje u istom kućanstvu, prva tri naraštaja srodstva međusobno) te rodbina kao zajednica u širem smislu (rodbina s kojom nema kontakata, dalja srodstva). Osjećaj zajedništva prema daljoj, rod-

obiteljskih okolnosti, mogu kršiti, nadilaziti, duboko poštivati i dr. Tada bi navođenje generalija zasigurno bilo izostavljeno, a podaci bi se sveli, primjerice, na lokalitet, spol i starosnu dob ispitanika.

22 Popis sugovornika Krivopućana naveden je na kraju rada. U nastavku rada, neka imena u tekstu neće biti navođena, onda kada autorice procjene da bi podatak, primarno u svrhu zaštite kazivača, trebao ostati anoniman.

23 Proširenim obiteljima mogli bismo smatrati višebrojne obitelji, sastavljene od nekoliko nuklearnih, kao i višegeneracijske obitelji, u jednom kućanstvu. Isto tako, termin bi se mogao odnositi i na zadruge koje su, većim dijelom obiteljske zajednice, koje su i višebrojne i višegeneracijske, ali se pored toga, ističu i strukturom vlasničkih odnosa.

24 Nuklearnim obiteljima smatramo one sastavljene od roditeljskog para s djecom, u jednom kućanstvu.

25 Ipak, u okviru ovog rada, naglasak neće biti stavljen na značenjska određenja i pojmovnu diferencijaciju, jer, u razgovoru, ispitano stanovništvo nije razgraničavalo obitelji na razinama nuklearnih i proširenih.

26 Usporedi ovu tvrdnju s podatcima koje donose suatori dvaju priloga: o demografskim promjenama krivoputske mikroregije od 17. stoljeća do danas (Husanović-Pejnović, Pejnović) i o podatcima koje donosimo analizom statusa animaruma za župu Krivi Put, u razdoblju druge polovice 18. stoljeća do polovice 19. stoljeća (Rubić, Vuković) u ovom svesku Monografije.

27 Tomo Špalj Cucin, Špalji; Mladen Šojat Bilin, Francikovac.

28 Dodatan kat je tijekom niza godina postupno dograđivan.

29 Primjerice, s izdvojenom spavaćom sobom, katkad i kupaonskim prostorom, i sl.

30 Više o tome vidi u odlomku: Potencijalni sukobi: I njihov se veš na štriku svada! 
binskoj zajednici je češće na simboličkoj (poštovanje), nego stvarnoj razini (suživot u istom kućanstvu, u istoj lokalnoj zajednici, kontakti)

Pojmove obitelj i rodbina kazivači katkad jasno razlikuju smještanjem istih u različit vremenski kontekst: Obitelj, recimo, sada ja, kad imam svoju ženu, i moja djeca, a familija, isto to se zvalo, recimo, u kucí, to neko zove familija, a neko kaže mi smo u familiji ili mi smo rodbina, a zovu se i familija u kući, a žena i muž $i$ djeca. A ta familija u kući je bila, djeca strica i njegova, $i$ dobro, to sve se računa - familija. Isto smo zvali familija, a sad se obitelj, otac i majka i djeca, da je to obitelj, a prije se kaže: Vid, puna kuća familije! Tu su bile tete i strici, baka i djed, ko sto je bilo kod mene, njih dvanaestero. I stric, ako ste zajedno bili, stric, stričeva familija ${ }^{31}$.

Dijelom uže obitelji smatraju se najčešće: otac, mater i djeca, a u širem obliku, i roditelji vjenčanog para, stric i strina te njihova djeca. Uočavamo kako stric (očev brat) ima simbolički istaknutu ulogu, određenu ponajprije patrijarhalno ustrojenim vrijednostima. Stric i stričeva obitelj, kako je već spomenuto, nerijetko su smatrani dijelom uže obitelji. ${ }^{32}$ Također, istraživanjem je otkriveno kako je na području Krivoga Puta bilo uobičajeno da braća žive zajedno u istoj roditeljskoj, kući i nakon ženidaba ${ }^{33}$ : Sve dok se nisu podijeli. A kad su jeli i pili iz jedne čaše onda su bili familija ${ }^{34}$. Djeci u takvom kućanstvu je stoga suživot sa stričevom obitelji značio užu obitelj koja dijeli mjesto pod zajedničkim krovom. ${ }^{35}$

$S$ druge strane, širom se (daljom) rodbinom smatraju oni od drugog, trećeg koljena, od bratića i sestrane djeca $^{36}$. Taj je dio rodbine smatran važnim segmentom obitelji prvenstveno u simboličkoj smislu, na razini poštivanja: Prvo se to sve puno poštivalo, di je i malo kapi krvi ${ }^{37}$. Ipak, i tu postoje razlike: ženina se obitelj, u odnosu na muževu, smatrala manje značajnom, a to eksplicitno potvrđuju svi kazivači. Takvo se vrijednosno poimanje u praksi manifestiralo u češćem i čvršćem održavanju kontakata s muževom obitelji i to, ističe se, prije temeljem odnosa poštivanja, nego zbog jake emocionalne privrženosti. ${ }^{38}$

\section{RODBINSKI NAZIVI}

$\mathrm{T}$ emeljem provedenog terenskog istraživanja o obitelji i obiteljskim odnosima na području Krivog Puta uočavamo nejasnoće i značenjske razlike u rodbinskom nazivlju; katkad se isti nazivi koriste za različite osobe. $S$ druge strane, autorice ovog priloga su se tijekom terenskog istraživanja suočile s nedostatkom vlastitog iskustva sustavnog bavljenja temom terminologije srodstva, kao i simboličkim značenjima pojedinih naziva. Bolje poznavanje poznatih klasifikacija i terminoloških sustava, uvelike bi olakšalo etnološko istraživanje rodbinskog nazivlja.

Značajno je stoga spomenuti rad etnologinje Ive Pleše, kao istaknut prilog etnološkom promišljanju terminologije srodstva (1998. (3) $^{3}$. Autorica podcrtava značaj terminologije srodstva kao predmeta etnološkog istraživanja, obzirom da su nazivi „povezani sa sustavima srodstva, a time $i$ s pojedinim društvenim odnosima unutar neke skupine" " 40 Rad I. Pleše je analiza temeljena na etnološkoj i antropološkoj literaturi, kojom se ciljano problematizira i propituje šira terminologija srodstva.

31 Tomo Špalj Cucin, Špalji.

32 Isti kazivač. U tom slučaju kod nekih je kazivača uporabljen i termin familija, kao sinonim užoj obitelji. Kazivač je nadodao kako je familija tek neznatno širi pojam koji može obuhvati sve one koji žive ili su donedavno živjeli u jednom kućanstvu.

33 Vidi o tome više dalje u prilogu, u odlomku naslova Suživot dviju nuklearnih obitelji.

34 Tomo Špalj Cucin, Špalji.

35 Isti kazivač.

36 Mladen Šojat Bilin, Francikovac.

37 Marija Prpić Nikolčina, Francikovac.

38 Marija Prpić Nikolčina, Francikovac; Mladen Šojat Bilin, Francikovac.

39 Pleše 1998:59-78.

40 Ibid.:77. 
U svakodnevnoj komunikaciji, tijekom cijelog 20. stoljeća do danas, upotrebljavali su se rodbinski nazivi ${ }^{41}$, od kojih su se neki tijekom vremena mijenjali, nestajali, ili su bivali zamijenjeni drugima ${ }^{42}$.

Prema Williamu Havilandu ${ }^{43}$, srodnička terminologija se prilagođava vrstama srodničkih skupina (spol, dob, naraštaj) koje postoje u svakom sustavu terminologije srodstva, i pomažu razlikovanju jednih od drugih rođaka, ispunjavajući dva važna zadatka: klasificirajući ili razdvajajući osobe unutar rodbine u slične ili posebne kategorije ${ }^{44}$. Ipak, veliki broj naziva zabilježen prilikom istraživanja na području Krivoga Puta, ne znači istodobno da ti nazivi pokrivaju sve vrste i stupnjeve srodstva ${ }^{45}$. Naime, očeva i majčina sestra obje su zvane tetkom, odnosno, tetom. U direktnom obraćanju uvijek je iza naziva slijedilo osobno ime osobe. ${ }^{46}$ Teta ili tetka je jedan od rodbinskih naziva koji se prenio na osobe koje nisu dio rodbine: Onda se [tijekom 20. stoljeća, op.a.] nije zvalo imenom, nego - teta, a svoje prave tetke koje su očeva sestra, majčina sestra zvali bi - tetka, a sada je došao običaj da se i svoje zove teta. ${ }^{47}$ Tako je i I. Pleše istaknula kako "preispitujući tvrdnju da u hrvatskom jeziku postoji poseban naziv za svakoga člana rodbine i svojte, odmah se mogu nočiti nazivi koji se u Rječniku rodbinskih naziva ponavljaju, odnosno, koji označavaju dvije vrste srodnika. Takav je naziv tetka, koji označava i očevu i majčinu sestru (... “"48

Krivopućani su tijekom 20. stoljeća u direktnom obraćanju rodbinske nazive koristili kao iskaz rodbinske pripadnosti i znak poštovanja prema osobama koje su dio rodbine. Dodavanjem rodbinskoga naziva ispred osobnog imena osobe prema kojoj se vrši obraćanje, poput: teta, strina, djed i sl., osobi se iskazivao status u rodbinskom i društvenom kontekstu, odnosno, rodbinska se pripadnost isticala kao društvena vrijednost. ${ }^{49}$

Najprisutniji zabilježen naziv za oca obitelji je ćaća, odnosno, ćaće, a pojavljuje se i naziv tata. Zanimljivo je kako se prilikom direktnog obraćanja sina ocu, koristio i drugi rodbinski naziv; nakon što mu se sin više puta obratio sa: djede, Marko Pavelić Mijatin je pojasnio: Ha, to je od dragosti. Takvi primjeri obraćanja roditelju s nazivima djed ili $b a b a$, potvrđeni su u više lokaliteta krivoputskog područja ${ }^{50}$. Nakon rođenja djeteta (unuka/unuke), nazive djed, odnosno, $b a b a$ ne koriste samo njihovi unuci u direktnom obraćanju, već i njihovi roditelji kada se obraćaju svojim roditeljima, u prisutnosti ili neprisutnosti unuka. Prema Markovim riječima, njegova je supruga svoju svekrvu (punicu) nazivala majkom, a nakon rođenja djece, bakom. Tome Špalj Cucin je, primjerice, svojeg oca skoro zva ćaće, a poslije, kada je došao unučić, onda smo ga zvali dede, did, ja koliko se sićam.

Rodbinski naziv za majku ima više lokalnih varijanti, a razlikuje se i među pojedinim obiteljima. Zlata Tomljanović Pešina iz Krivog Puta, primjerice, ističe kako se u njezinoj obitelji kako pamti, oduvijek koristio naziv mlada mama. U ostalim lokalitetima zabilježeni su nazivi: majka i mama, od kojih se ovaj drugi nešto rjeđe pojavljuje i to kod kazivača rođenih sredinom 20. stoljeća, dok stariji ${ }^{51}$ pretežito koriste naziv majka.

41 Neki autori upotrebljavaju termin rodbinska imena. Vidi: Ivanišević 1987:331; prema: Pleše 1998:63.

42 Vidi više o tome dalje u prilogu.

43 W. Haviland je američki kulturni antropolog.

44 Haviland 2004:246.

45 Pleše 1998:73.

46 Pavla Pavelić Ćirilova, Mrzli dol; Mladen Šojat Bilin, Marija Prpić Nikolčina, Francikovac.

47 Zlata Tomljanović Pešina, Krivi Put.

48 Pleše 1998:64.

49 Postojanje mnoštva rodbinskih naziva, i njihova vrlo intenzivna uporaba u svakodnevnom diskursu, može značiti jak intenzitet simboličke povezanosti, bez obzira na činjenicu dijele li članovi u srodstvu isti fizički prostor, odlikuje li ih zajedničko stanovanje ili usmeni kontakt.

50 Francikovac, Krivi put, Špalji i Žuljevići.

51 Rođeni tridesetih godina 20. stoljeća. 
U prvoj polovici 20. stoljeća, do nakon Drugog svjetskog rata, bilo je obitelji u kojima su se djeca, prema naučenom obrascu poštivanja roditelja i starijeg, roditeljima obraćala sa - Vi. Govorilo se: Vi ćaća, Vi mama. ${ }^{52} \mathrm{~S}$ vremenom, u drugoj polovici 20. stoljeća, takvo se obraćanje roditeljima postupno izgubilo. Nazivi za kćer i sina se ne razlikuju među lokalitetima, već se svugdje koriste nazivi: ćer i sin. Roditelji supružnika međusobno se nazivaju prijatelj i prijateljica i njihov novi odnos, stečen sklapanjem braka njihove djece, nalaže da se međusobno poštivaju. ${ }^{53}$

Kod naziva za $b a k u$ i djeda postojale su razlike između pojedinih obitelji. Ipak, najuvrježeniji nazivi su: baba i djed, did: I dan danas mene moji zovu - baba. Ja sam to htjela, da oni mene zovu "po krivoputski“ - baba, prisjeća se Zlata Tomljanović Pešina. Kao djevojka svoju je baku počela zvati baba, a ranije su je, sjeća se, ostali članovi obitelji nazivali starom mamom/majkom. U Špaljima se baku također nazivalo babom $^{54}$. Braća i sestre Tome Špalja Cucinog iz Špalja, svoju su baku (očevu majku) zvali: stara majka, a djeda stari tata, kako je zabilježeno i u Francikovcu ${ }^{55}$. Prema Tominim riječima, njegova su oca, kasnije, djeca nazivala ćaće, te je taj naziv u Špaljima postojao paralelno s nazivom stari tata: Moja braća su zvali moga dida ćace, a tako ga je i tata moj zva.

Pojedini nazivi eksplicitno su određivani kao vrijednosno različiti, pri čemu korištenje određenih rodbinskih naziva odražava društvenu stvarnu ili prividnu diferencijaciju. Primjerice, Marija Prpić Nikolčina iz Francikovca kaže kako su se nazivi za baku i djeda, u Francikovu i Vrataruši koristili u obliku stara mama i stari tata, no, to su bili rjeđe korišteni nazivi i njima se isticalo poznavanje starine, kako je prvo bilo: Ne svi, neki su zvali, a znate šta, to su vam više neki ljudi koji su kao htjeli kao da su oni odskočili kao od nas.

Pavla Pavelić Ćirilova iz Popića, s druge strane ističe kako se razlikovanje vršilo na razini: katolička i pravoslavna sela. U pravoslavnim selima baku se nazivalo starom mamom, kao izraz poštovanja jer ona je ipak rodila vlastitu majku. Nazivi koji se izvode iz naziva baka i djed, jesu: prabaka i pradjed, odnosno, prababa i pradid. ${ }^{56}$

Nazivi za dalju rodbinu, izvan uže obitelji, također su raznovrsni. U svakodnevnom diskursu mladi starije osobe (bilo iz rodbine ili izvan nje) ne oslovljavaju sa $t i$, već im se, iz poštovanja, obraćaju sa $V i$. Ako je riječ o osobi koja je dio rodbine, u direktnom obraćanju se ispred imena uvijek stavlja rodbinski naziv. Pritom se uočavaju razlike u nazivlju rodbine s očeve is majčine strane. Sami kazivači tu su razliku znakovito vrijednosno naglašavali, eksplicitno ili implicitno dajući veći značaj rodbini s muške strane. Majčin brat nosi rodbinski naziv ujak, dok, $s$ druge strane, očev brat nosi naziv stric. Pretpostavka je da ta diferencijacija leži u vrijednosnom izdvajanju jednog u odnosu na drugog, u smislu patrijarhalnih obrazaca mišljenja i ophođenja. Ta se razlika ne proteže uvijek na ženske članove. Ne postoji razlika u nazivu za majčinu i očevu sestru. Obje su tetke, ili, u novije vrijeme, tete. Stričeva žena, ipak, dobiva naziv izveden iz njegovog - strina. Majčin brat ujaclujak određuje naziv za njegovu ženu - ujna. Polovicom 20. stoljeća korišteni su nazivi ujac i ujna, što je zabilježeno u mjestu Špalji, u kojemu danas, kako ističe Tomo Špalj Cucin, njegovi nećaci njega nazivaju ujom, jer to je sad po novoj modi.

Djeca od strica i ujaka nose isti naziv - bratić i sestrična, odnosno, bratučed i sestrana, nazivi koji su se koristili u prvoj polovici 20. stoljeća. Ti nazivi koriste se za rodbinu s očeve, kao i s majčine strane. ${ }^{57}$ Bratovo dijete naziva se sinovac, odnosno, sinovka. ${ }^{58}$ Taj se naziv (i za muškarca i ženu) danas izgubio i

Mladen Šojat Bilin, Francikovac; Tomo Špalj Cucin, Špalji.

53 Zlata Tomljanović Pešina, Krivi Put; Tomo Špalj Cucin, Špalji.

54 Tomo Špalj Cucin, Špalji.

55 Mladen Šojat Bilin, Marija Prpić Nikolčina, Francikovac.

56 Milka Prpić Markina, Veljun.

57 Tomo Špalj Cucin, Špalji; Zlata Tomljanović Pešina, Krivi Put.

58 Marko Pavelić Mijatin(a), Zlata Tomljanović Pešina, Krivi Put; Milka Prpić Markina, Veljun; Tomo Špalj Cucin, Špalji. 
zamijenjen je nazivima: nećak, nećakinja, što je prvotno označavalo isključivo tetku i djecu njezine sestre. ${ }^{59}$ Djeca tetke i tetka, te ujaka i ujne, nazivaju se nećakom i nećakinjom, odnosno, netjak i netjakinja. ${ }^{60}$ Naziv netjak doživio je tijekom druge polovice 20. stoljeća promjenu pa se danas češće koristi naziv nećak. ${ }^{61}$

Ženidbom i udajom se pridružuju novi članovi obitelji i rodbine. Time se povećava i broj korištenih rodbinskih naziva. Nazivljem se razlikuju muški i ženski rođaci stečeni udajom, odnosno, ženidbom. Mužev brat ženi postaje djever, odnosno diver. ${ }^{62}$ Žene od dva brata postaju jetrve. ${ }^{63}$ Suprugova sestra ženi postaje zaovom ili zavom, dok žena njoj i njezinim roditeljima postaje nevistom. ${ }^{64}$ Suprugu je sestrin suprug svak, a bratova žena svastika. ${ }^{65}$

Nadalje, brat udane žene je njezinom suprugu šurjak. ${ }^{66}$ Suprug njemu i njegovim roditeljima postaje zetom. ${ }^{67}$ Ipak, suprug i ženin brat češće obojica koriste naziv šurjak u međusobnom obraćanju.

Pašanci, paši su jedan drugome muževi dviju sestara ${ }^{68}$ : To je, ako smo nas dva uzeli dvje sestre, oženili, onda bi bili pašanci. ${ }^{69}$ Paši, mi smo govorili. ${ }^{70}$

Nevjesta, nevista je mlada koja, nakon udaje i prelaskom u novo kućanstvo, svim ukućanima postaje nevistom. Ona je nevista ocu i majci i muževoj braći. Isto je kao i kod naziva zet; on bi ženinim roditeljima bio zet, ali ženinoj braći i sestrama je šurjak, odnosno svak. Osim naziva nevjesta koristio se i naziv snaja, ali vrlo rijetko. Većina kazivača ističe kako je taj naziv preuzet iz kontinentalnih krajeva Hrvatske.

Nevjesta i zet roditelje supružnika nazivali su punicom i tastom. Naziv punac rijetko se koristio u direktnom obraćanju. ${ }^{71}$ To su termini koji se koriste samo kada bi se eksplicitno objašnjavala njihova uloga u obiteljskom stablu, no, u svakodnevnom ophođenju se ne koriste. U razgovoru nevista punicu oslovljava - majko, a tasta - tata. U novije vrijeme, od sedamdesetih godina 20. stoljeća, mlade nevjeste svoje svekrve sve više nazivaju drugim rodbinskim nazivom: teta, ili im se obraćaju samo sa Vi: Prije je bio je bio običaj zvati svekrvu majkom, koje bi ženske došle svoju svekrvu bi zvale majkom, a sada je zovu tetom, a neko zove mamom, a mene moje zovu mamom i babom. ${ }^{72}$ Marija Prpić Nikolčina je u razgovoru podržala obraćanje sa $V i$ istaknuvši: Ako muž poštiva moje roditelje, onda što ja ne bi njegove. Nadalje, na cijelom ispitanom području Krivog Puta potvrđena je česta uporaba rodbinskog naziva teta, od sedamdesetih godina i u današnje vrijeme, primjerice, kako to Mladen Šojat Bilin ističe: Ja znam puno mladih nevista da zovu svekrvu tete, a i punicu zove teta.

59 Zlata Tomljanović Pešina, Krivi Put.

60 Zlata Tomljanović Pešina, Krivi Put; Tomo Špalj Cucin, Špalji; Marija Prpić Nikolčina, Mladen Šojat Bilin, Francikovac.

${ }^{61}$ Zlata Tomljanović Pešina, Krivi Put.

62 Marko Pavelić Mijatin(a), Zlata Tomljanović Pešina, Krivi Put; Tomo Špalj Cucin, Špalji; Milka Prpić Markina, Veljun.

63 Pavla Pavelić Ćirilova, Mrzli dol; Tomo Špalj Cucin Špalji; Marko Pavelić Mijatin, Žuljevići; Milka Prpić Markin(a) ova, Veljun.

${ }^{64}$ Tomo Špalj Cucin, Špalji; Mladen Šojat Bilin, Marija Prpić Nikolčina, Francikovac.

${ }_{65}$ Tomo Špalj Cucin, Špalji; Mladen Šojat Bilin, Marija Prpić NIkolčina, Francikovac. Tijekom istraživanja zabilježili smo šaljive stihove: Imam ženu i svastiku, obadvije prave gimnastiku, koje nam je bio rekao Mladen Šojat Bilin.

${ }_{66}$ Tomo Špalj Cucin, Anka Špalj Cucina, Špalji; Marko Pavelić Mijatin(a), Žuljevići; Zlata Tomljanović Pešina, Krivi Put; Mladen Šojat Bilin, Marija Prpić Nikolčina, Francikovac.

67 Tomo Špalj Cucin, Špalji; Mladen Šojat Bilin, Francikovac.

68 Marko Pavelić Mijatin(a), Žuljevići; Paola Pavelić Ćirilova, Mrzli Dol; Zlata Tomljanović Pešina, Krivi Put; Tomo Špalj Cucin, Špalji; Mladen Šojat Bilin, Francikovac.

69 Marko Pavelić Mijatin(a), Žuljevići.

70 Tomo Špalj Cucin, Špalji.

71 Marko Pavelić Mijatin(a), Milka Prpić Markina, Veljun.

72 Zlata Tomljanović Pešina, Krivi Put. 
Rodbinski nazivi koriste se katkad i u razgovoru sa starijim susjedama, s nekim tko nije dio rodbine, ali koga se smatra bliskim: Kod nas se zvalo tatinu sestru, rečemo tetka, nije teta, a ove babe sto su bile od nas starije - teta, baba - teta, a tetka je tatina sestra ili mamina..$^{73}$ Isto potvrđuje i kazivanje zabilježeno u Francikovcu: Obično si komšiju starijeg zvao stricom ${ }^{74}$ Kako smo se kojoj naučili. Mi smo ovdje imali jednu, ta je bila, njezin mužje nam bio vjenčani kum, tu smo zvali, ja sam ju zvala kuma, a ovi su je svi drugi zvali teta Mara. A jednu smo imali baku, tu smo svi zvali - majka. A njezinog - ćaća, starog muža joj. Tako su zvali svi, i dica, i mladi i stari, ćaća i majka. To kako koga naviknu zvat. Nekome teta, nekome strina, nekome kuma $i$ tako. I nije se prvo starim ženam govorilo ti, nego vi. Lipo pozdravi, a danas proleti ka majmun. ${ }^{75}$

Većina kazivača rodbinske nazive i danas koristi u svakodnevnoj komunikaciji. Obraćanje se često i ne vrši imenom, već, iz poštovanja i dragosti, rodbinskim nazivom. Mladi korištenjem rodbinskih naziva izražavaju poštovanje prema starijima: Stariji se poštiva svako. Nema veze što je, je li rod, je li susjed i svakog. ${ }^{76}$ Obraćanje rodbinskim nazivom vrši se, bez iznimke, u padežu vokativu. Tako se, primjerice, kaže: diveru, ili, svaku. Muž i žena jedan drugog su, tijekom 20. stoljeća, prema kazivanjima svih kazivača, oslovljavali imenom, a to čine i danas.

Pojedini nazivi su doživjeli promjenu, nestali iz uporabe, ili su zamijenjeni već postojećim, drugim rodbinskim nazivom. Primjerice, sinovac i sinovka (bratov sin i kćer muškoj osobi) su zamijenjeni nazivima: nećak i nećakinja. Nazivi bratučed i sestrana zamijenjeni su nazivima: bratić i sestrična. Vremensko razdoblje, kao i razlog tih promjena, ne mogu se jasno odrediti. Najvjerojatnije je riječ o praktičnim razlozima, jednostavnosti oslovljavanja, ili pak u manjem značenju članova šire rodbine u svakodnevnom životu pojedinca (uslijed raseljavanja članova iz uže lokalne zajednice).

Bogat sustav nazivlja rođaka, koji se stječu ženidbom, kao što su: zaova, diver/djever, jetrva, svak/svaja i pašanac, zamjenjuje u novije vrijeme jedan uopćeni naziv - šogor, odnosno, za žensku osobu - šogorica.

Uporabna terminologija srodstva (nazivi koji se koriste u osobnom obraćanju) na području Krivog Puta danas (2006.) općenito pokazuju tendenciju za smanjenjem raznovrsnosti korišstenih naziva ${ }^{77}$.

\section{UTJECAJ SIROMAŠTVA NA OBITELJSKI ŽIVOT}

$\mathrm{K}^{\mathrm{n}}$ roz razgovor o obitelji kazivači su vrlo često isticali različitost današnjeg načina života u odnosu na vrijeme njihove ženidbe i udaje, ili ženidbe i udaje njihovih roditelja ${ }^{78}$.

Sedamdesetih godina 20. stoljeća na području Krivoga Puta uslijedila je znatnija transformacija obiteljskih struktura, prije svega uslijed intenzivnijeg iseljavanja u obližnja urbana područja (u gradove Rijeku i Senj) te povremenih radnih migracija u druge hrvatske regije. ${ }^{79}$ Otvaranjem tvornica u Senju ${ }^{80} \mathrm{i}$ državne pilane na Krivome Putu ${ }^{81}$, započela je industrijalizacija ovog kraja, što je utjecalo i na (trajnije

\footnotetext{
73 Tomo Špalj Cucin, Špalji.

74 Mladen Šojat Bilin, Francikovac.

75 Pavla Pavelić Ćirilova, Mrzli Dol.

76 Ista kazivačica.

77 Isti nazivi upotrebljavaju se za više srodnika (primjerice, bakom postaje i prabaka) ili se stvara novi naziv, koji označuje više srodnika (primjerice, didak i pradid postaju: dido), kako, prema literaturi, uočava i I. Pleše (1998: 75). Na području Krivoga Puta takve i slične promjene potvrdili su svi ispitani kazivači.

78 Opisi se odnose na prvu polovicu 20. stoljeća, za vrijeme stare (kako lokalno stanovništvo govori, a misli se na Kraljevinu) Jugoslavije te prije, za vrijeme, i netom nakon Drugoga svjetskog rata.

79 Odlazak u gradove i druga područja, te iseljavanje s područja Krivog Puta, šire su obrađeni u okviru priloga Marijete Rajković, o recentnijim migracijskim procesima, u prvom svesku Monografije, str. 79-94, kao i u prilogu o demografskim karakteristikama ovog područja Danice Husanović Pejnović i Dane Pejnovića, u ovom svesku Monografije.

80 Primjerice, tvornica donjeg rublja „Neda“ u Senju.

81 Pilana u Alanu, zatvorena 1966. godine (Rajković 2008:85).
} 
ili privremeno) rasipanje obitelji. Radna migracija zahvatila je mahom i direktno muškarce koji su čak mjesecima bili odsutni iz kuće (Usp. Rajković 2008:82-86). Vrlo je važno radne migracije promatrati u kontekstu utjecaja siromaštva na obiteljski život. Nerijetko su ljudi privremeno i trajno iseljaval,i ponajprije u potrazi za poslom, ostavljajući svoje obitelji (čitaj: žene i djecu), dok bi imućniji ostajali, što je protivno stereotipnom poimanju migracijskih procesa (Usp. Ibid.: 98). Kazivači ističu težak život prvo ${ }^{82}$, u pogledu mukotrpnog ručnog rada i općeg siromaštva - nepostojanja sistema mirovina i državne pomoći (što je uslijedilo u socijalističkom razdoblju). Ističući važnost uvođenja socijalnih državnih mjera za vrijeme Titine (socijalističke, op.a.) Jugoslavije, Milan Prpić Markin iz Veljuna se, primjerice osvrnuo na opis društveno-gospodarskih prilika prije i nakon Drugog svjetskog rata: To su nekadašnja vremena teška bila. Nije se dalo do ničega doći. Ovo sad, otkad je Tito, to svi na njega galame, a Tito je majka bio, za radnika. Nije radio onaj 'ko nije tija radit, a svako je posa moga dobit!' I najmanje dite! Samo ako hoćeś delat. To je prije bila muka Isusova. Za vrijeme stare Jugoslavije nije se posa' dobiva. I ono prvo, cijelu zimu traži sirota posla, dođe kući, i goli i bosi, i dinara nije zaradila nigdje. Nije bilo zarade. A danas sve to, vidiš, dalo se omladini prednost,... pa i treba i omladina imat, na njima ostaje, ali nekada se išlo i golo i boso i svakako. Nije bilo ni škole. To se počelo obnavljat tek kad je Tito doša, da je natera sve. Nije tu bilo nekih puteva, ničega, to je jedna pustinja velika bila.



Slika 2: Pilana Alan, mjesto zapo.ljavanja mu.ke polulacije, 60-te godine 20. stoljeća (foto Arbiv GMS)

Muškarci s područja Krivoga Puta su, do otprilike sedamdesetih godina 20. stoljeća, radili u šumi na izvlačenju trupaca, ili na izgradnji cesta ${ }^{83}$. Primjerice, Milan Prpić Markin(a) iz Veljuna je radio na cestogradnji te se prisjeća kako je to bio dobro plaćen, ali mukotrpan i, u pogledu pružanja sistema socijalne sigurnosti (radnoga staža), nesiguran posao. Također, takvi su poslovi značili i višemjesečnu odsutnost. Prisjeća se rada na izgradnji cesta: Od cesta, to je uvijek nesigurno, socijalno to, to je drugo, to se razlikuje od zarade, jer mi smo dobru zaradu imali, al' nam nije ni'ko prizna' to. I onda su ljudi patili, ja sam ti patija ka' Isus, I ti svi radnici, pješke kad se ide, put, zimi je iša' autobus jedan za Trst i ja sam sjeo u njega, u četiri sata je otiša' zadnji za Rijeku i sjedni sam i tamo do Vratnika točno u pol noći dodi, a mećava, oluja, snijeg do zubi! A kad dođeš mokar pa čekaj autobus pa smrzneš se k’o led ledeni! Teško je bilo, radili smo k’o vrag, k’o životinje, zato sam ja reka', to vražje misto. Ja sam sretan što su mi dica napustila ovo. Marko Pavelić Vranićev iz Pa-

82 Što se odnosi na vrijeme stare (Kraljevine, op.a.) Jugoslavije.

83 Milan Prpić Markin(a), Veljun; također usporedi prilog o tradicijskoj trgovini i sajmovanju autorice Tihane Rubić, u prvom svesku Monografije, str. 338-340. 
velića također se prisjeća rada u šumi kao teškog i mukotrpnog, te kako je rad započeo već sa 17 godina. Ipak, ističe kako je radni staž sjekača bio benificiran, što opet ukazuje na mukotrpnost takvog posla: Ja sam sve godine radio u šumi najprije u siječi drva, ručnom pilom, pa motornom, a onda na utovar elemenata, a kasnije sam otišao u Senj, trpali smo trupce na brodove i išli smo u šumu makljat celulozu sa drveta, jer to kao nije valjalo. Samo sam ja sad već dugo u penziji, 22 godine, a ja sam ima 35 godina staža kad sam otiša, jer mi koji smo radili u šumi imamo beneficirani radni staž kao sjekač. Svi kazivači ističu mukotrpnost kao osnovnu karakteristiku tih poslova, no, istovremeno i nužnost financijskog skrbljenja za obitelj: Ja na terenu, na poslu, nema me kod kuće, al' morali smo držat' posa', nemaš šsto jest ${ }^{84}$.

U potrazi za boljim životnim i radnim uvjetima, odlazak radno sposobnog mladog stanovništva s područja Krivoga Puta u gradove predstavljao je uglavnom stalnu tendenciju i proces tijekom čitavog 20. stoljeća. ${ }^{85}$ Stanovništvo Krivoga Puta sa svojim je obiteljima iseljavalo najčešće u gradove: Senj ${ }^{86}$, Rijeka ${ }^{87}$, Novi Vinodolski ${ }^{88}$, u kontinentalne gradove: Zagreb ${ }^{89}$ Gospić $^{90}$ i Kutinu ${ }^{91}$, ili dalje, primjerice, na otok $\mathrm{Rab}^{92}$, vrlo često u Slavoniju ${ }^{93}$ (Ćaćinci, Požega, Lasinje, Vinkovci, okolica Bjelovara), dijelom u Vojvodinu (Kikinda) ${ }^{94}$, te čak u prekomorske zemlje: Ameriku ${ }^{95}$, Kanadu ${ }^{96}$ i Brazil (Brasillia) ${ }^{97}$, u potrazi za poslom. Temeljne razloge iseljavanja lokalno stanovništvo vidi u općem siromaštvu kraja, u nezaposlenosti, slabom razvoju privrede, oskudnom tlu, jakoj buri i općenito slaboj naseljenosti stanovništva. Nepovoljne vremenske prilike su stalno prisutna karakteristika kraja, koja je tjerala ljude na iseljavanje: Zimi je zlo. Pa zatvori promet pa tu dode na osam dana da ne pročisti. I nestane struje i to je ono. Tu su i jake bure i vjetrovi. Jedino priko lita, nema di lipše nego tu, zato što je čist zrak, nema zagadenja ${ }^{98}$. Česta su, stoga, bila iseljavanja s krivoputskog područja u Slavoniju: Težak je život ovde, tu nemaš ništa, to je sirotinja, to je zemlja porozna tu, nije rodna. Evo smo mi morali sijati pšenicu, ječam, zob, kukuruz, čak i proso i heljdu. Mor'o si, jer nisi imao prihode za kruh, mor'o si odnekud. I na mlinicu se vozilo tamo u Brlog, prema Otočcu, tu, malo dalje. Za kruh. A trebalo je i za stoku nešto, za svinje hranit, mor'o si imat nešto ječma ili zobi, eto, tako. Najviše je naših ljudi zato otišlo u Slavoniju onda' ${ }^{99}$.

Navodeći ove razloge, stanovništvo naglašava razumljivost stalne tendencije iseljavanja s područja Krivog Puta. To se posebice odnosi na stariju populaciju, u mirovini, koja, slijedom navedenih uzroka, odobrava odlazak svojih mladih s područja Krivog Puta i prethodnog raseljavanja svoje braće i sestara iz obiteljske kuće, također u potrazi za zaposlenjem.

84 Isti kazivač.

85 Usporedi prilog Marijete Rajković o migracijama Krivopućana, u prvom svesku Monografije, str. 82-85.

86 Milka Prpić Markina, Veljun, Marko Pavelić Vranićev, Pavelići, Milan Cvitković, Katići.

87 Milan Prpić Markin, Veljun, Milka Prpić Markina, Veljun, Milan Cvitković, Katići.

88 Milan Krmpotić Zekonja, Veljun.

89 Milan Prpić Markin iz Veljuna: Završio je četiri razreda osnovne i otišao ča. Nije se ni vraća onda, a šta će, tamo se i školova i oženija se. Ne samo on, tako su svi otišli odovuda. Milka Prpić Markina iz Veljuna: Otišao je kod moje sestre, svoje tete. I sestra moja, udana, je u Zagrebu.

90 Milan Krmpotić Zekonja, Veljun.

91 Isti kazivač.

92 Milan Krmpotić Zekonja iz Veljuna: Kíer je delala tu jedno tri godine, četiri. A onda se udala i otišla na Rab. Dečko je dela u Senju na brodu, tovario je trupce za Italiju, vozio iz Italije, dolazija tu, tako su se upoznali i... spasila se, dite moje, spasila.

93 Milan Krmpotić Zekonja, Veljun; Milka Prpić Markina, Veljun; Pavla Pavelić Vidina, Veljun; Milan Cvitković, Katići.

94 Milan Krmpotić Zekonja, Veljun.

95 Marko Pavelić Mijatin(a), Žuljevići.

96 Pavla Pavelić Vidina, Veljun.

${ }_{97}$ Milan Krmpotić Zekonja, Veljun.

98 Isti kazivač.

99 Milan Prpić Markin, Veljun. 
Iz obližnjih gradova poneki iseljeni mještani danas tek povremeno (najčešće ljeti) navraćaju u sela Krivog Puta (da provjetre kuću, okopaju zemlju ili vikendom s manjom djecom proborave u rodnom mjestu).

Odlazak na rad, trbuhom za kruhom ${ }^{100}$ (Usp. Rajković 2008: 96) te trajno preseljenje u gradove i druga područja Hrvatske, kazivači bez iznimke ocjenjuju dobrom odlukom, podvlačeći siromaštvo vlastitog kraja kao temeljni poticaj za odlazak. Najveći broj djece rođene dvadesetih i tridesetih godina 20. stoljeća ${ }^{101}$ raselilo se iz obiteljske kuće nakon udaje ili ženidbe: Nije moga’ ovdje živjet svi, pa je ne’ko osta', ne’ko otiša, bježa'. Tak 'ko je bježa', taj je bija pametniji. Moj muž je ostao što nije volija ič dalje, što je volija delat na zemlji, ali što sad ima od nje, nema ništa k’o ni mi (ona, sin i snaha) danas, ništa ${ }^{102}$. Pritom u obiteljskoj kući ostaje jedno (najčešće muško) dijete koje dohranjuje i uzdržava roditelje u starosti (starčenje) te dobiva obiteljsku kuću u nasljeđe kao imovinu, dok se druga braća odriču svog dijela. Katkad je, tijekom 20. stoljeća, u kući ostajao najstariji brat, no, to nužno nije bilo pravilo: Ha, koji će ostat nek' ostane, a mi drugi idemo ča i gotovo. Oni moraju ičc ča, a jedan mora oca i mater dohranit. Nema tu. ${ }^{103}$

Često bi u kući ostajao zadnji neoženjeni sin, jer bi ostala braća i sestre, oženjeni i udani, ranije odselili. Isto tako, skromnost imovinskih prilika na području Krivog Puta nije omogućavala nasljedstvo veće od obiteljske kuće, zbog čega su mlade obitelji mahom i iseljavale u druge krajeve (puno njih u Slavoniju) te i danas, kada su mnoge kuće ostale prazne, ne postoji interes za povratkom, niti potražnja drugih ljudi za prodajom i ponudom tih kuća na tržištu: ono prvo ${ }^{104}$, je bio taj običaj stariji da ono ostaje tobož na njemu (najstarijem sinu) imanje, ali to doli po Slavoniji, di ima što ostat, a vrag će ovdje ostavit što, što će mu ostat? ${ }^{105}$ Istovremeno, ističe nezadovoljstvo što je ostao u selu i naslijedio kuću: Ostala je, vraga svoga, pa mi to porez nabije, što nemam mirovine kako treba. Svi otišli ča, odrekli se, meni ostavili, meni, za vraga moga. Meni ostavi i ja plaćaj porez od mirovine. Moga sam imat bar dvadeset kuna više od mirovine. A od toga ništa nemam, moj se sin, ni jedan, neće tu nikada vratit. Mogu doć ispeć janje, tu u ladovini, al da će on tu, vrag, nikad više. Ako dođe turizam jedino... Također, Milan Zekonja iz Veljuna navodi slična razmišljanja u pogledu svog ostanka u selu: Mora sam ostat radi roditelja. Radi oca i matere. Kud će oni? Svi su odšli, da ja odem, kud će oni? Sve je odšlo to po svitu. Nakon što se oženio, jedno kraće vrijeme je još jedan brat živio u obiteljskoj kući dok se i on nije oženio, tako da sam ja, prisjeća se Zekonja, osta ovde radi oca $i$ matere. Da nije bilo njih živih možda ni ja danas ne bi bija ovde. Braća su se odrekla u korist mene, tako da sam ja samo vlasnik. Ali da ima tko, ja bi to sve prodao, da ima tko da hoće kupit, ja bi sve proda, i kuću $i$ stalu $i$ zemlju i traktor i sve bi ja proda. Bolje bi bilo da nisam ni ja osta. Da nije bilo oca i matere, ne bi ni ja. Ne moš ostavit starčenje. Kud će?

Također je i kćer katkad mogla ostati u obiteljskoj kući i naslijediti je $\mathrm{j}^{106}$. Ipak, čini se kako je to bila rijetka pojava, jer za takve slučajeve nije dobiveno konkretnih, kazivačima znanih, potvrda, mada bi se, daljnjim istraživanjem možda mogao zabilježiti neki slučaj, jer kazivači načelno govore kako je to bilo moguće. Isto tako govore o tome kako pri nasljeđivanju nije nužno vrijedilo pravilo najstarijega (Usp. Rajković 2008: 98), te da je kuća ostajala onom koji hoće, što dijelom govori o tome kako se kuća na području Krivog Puta nije smatrala posebno isplativom i vrijednom imovinom. Za takvo pimanje bilo je realne osnove, s obzirom da su kuće na ovom području bile skromnih i pojednostavljenih graditeljskih oblika, „kao odraz čovjekovih osnovnih egzistencijalnih potreba i mogućnosti“ (Šarić Žic 2008: 141). ${ }^{107}$

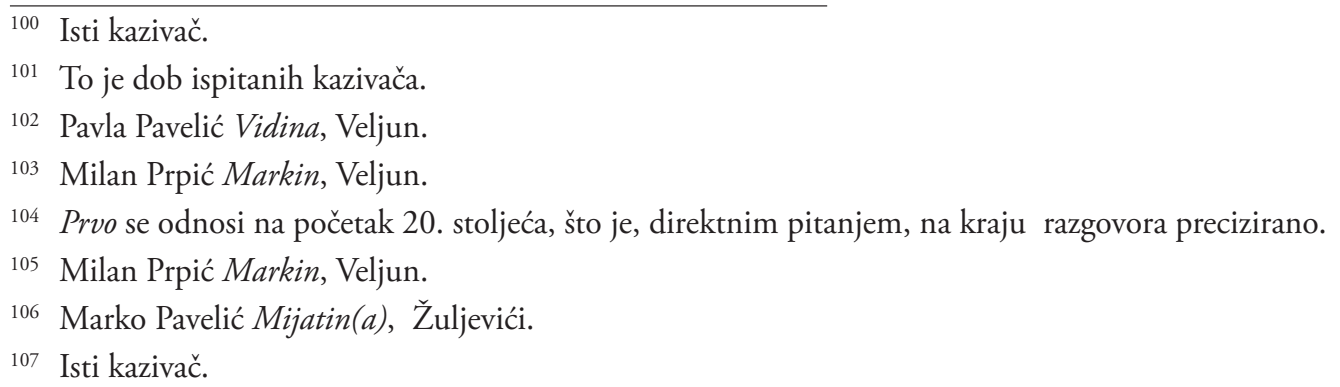


Zanimljiva je praksa, kao rezultat mnogobrojnosti djece i siromaštva, odlazak iz roditeljskog doma i mjesta stanovanja, što se nazivalo služenjem, ići služit. Podaci o odlasku na služenje zabilježeni su u mjestima: Šolići ${ }^{108}$ i Francikovac ${ }^{109}$ : Naše mlade djevojke il' su čuvale goveda, il' su išle služiti, od Senja do $Z_{\text {agreba }}{ }^{110}$. Djevojke su odlazile u navedene gradove kod gospode, pa su se tamo nešto $i$ naučile $i$ ostale ${ }^{111}$. $\mathrm{Na}$ služenje su djevojke odlazile tijekom prve polovice 20 . stoljeća, jer su se poslije rata ${ }^{112}$ sve zaposlile u tvornicama, a inače su sve služile ${ }^{113}$. (Usp. Vene 2008, u tisku)

Anka Šolić Tutanova iz Šolića jedna je od žena koje su kao četrnaestogodišnjakinje išle služit. Razlozi su bili: brojnost djece (njih devetoro) i siromaštvo. Žene su u okviru služenja u gradovima obavljale poslove u kući i oko kuće: Nas je bilo devetero djece, al' nigdje nije bilo ovako rada k’o sada ima. Ni tvornice, nigdje ništa. Otac bi otišo, on je bija obični zidar, iša je sa ru'sakom, pitaj Boga kuda, pješice. I tako bi tad donija, jer ljudi nisu zimi išli, nego su bili kod kuće, i onda od čeg ćešživit? Nas je bilo puno djece, išli smo služit. Ovdje je bila jedna moja rodbina, ona je otišla u Rijeku pa je naučila i talijanski. Išle su žene prat veš, peglat, u gradove. A ova koja nije otišla, ta je ovako služila kod koga, il mu blago čuva il dite malo čuva il tako.

Također su, sredinom 20. stoljeća, žene dnevno spravljale i nosile topli obrok muževima na radu u šumi. Anka Šolić Tutanova se prisjeća: Išle smo u šumu kuvat ljudim. Tu su se, jer ova naša šuma puna je bila ljudi od svakud. Bosanaca, tu su se drva izgonjala, šlajsa, moj je muž bija, on je ima konje, državne, pa sam i njemu kuvala, zato sam i ostala š njim onda u braku. [smije se, op. a.]

Prema pojedinačnim etnološkim istraživanjima, služenje u mnogim hrvatskim krajevima nije bilo rijetka pojava (Usp. Ibid.). Iako je riječ o teškom fizičkom radu, mnogo je muške i ženske djece, kao i djevojaka s područja Krivoga Puta, bilo prisiljeno privremeno ići služiti, a zbog neimaštine: Puno, puno je išlo. Nekom čuvat blago, ne’ko se javio, budi i sirotinja, sto krpa ima na gaćami i bosi i da budu sve puni trnja i stučeni i koščce ove, sve budi krvava, dici. Di je bilo jedno dite ili dvoje, onda je bilo bolje, a di je bilo više, tu je bilo dosta isto sirotinje. A bilo je, dosta, uvik puno dice. Nije bilo k'o sad. Onda nije bilo ni tol'ke pismenosti po selu. 'Ko je ima srednju školu?' Onda nije se ni znalo ${ }^{114}$.

\section{BROJ ROĐENE DJECE - PAD NATALITETA, RAZLOZI I VRIJEDNOSTI}

$\mathrm{D}$ o prve polovice 20. stoljeća žene su rađale veći broj djece u odnosu na danas (Usp. Rubić, M. Vuković, u ovom svesku Monografije). Iako je pored većeg broja rođene djece bila i veća smrtnost djece u odnosu na danas (Usp. ibid.), broj stanovnika na području Krivoga Puta u prošlosti je bio znatno veći nego danas, a razvidan je iz popisa stanovništva: „vidljiv je rast stanovništva do 1910. godine, da bi nakon tog razdoblja broj stanovnika stalno opadao. Do pada stanovništva naročito dolazi nakon 1961. godine..." (B. Ljubović 2008: 50). Službeni popisi stanovništva mogu dakle potvrditi razlike u broju stanovnika u prošlosti i danas, te trenove opadanja broja stanovnika, uzrokovane ponajprije iseljavanjem i sve manjim udjelom mladog stanovništva: „Današnji Mjesni odbor Krivi Put (...) po popisu iz 1981. imao je 599 stanovnika, a po popisu iz 1991. 449 stanovnika da bi po posljednjem popisu iz 2001. godine imao 495 stanovnika“ (ibid.:51; Husanović-Pejnović i Pejnović, u ovom svesku Monografije).

\footnotetext{
108 Anka Šolić Tutanova, Šolići.

109 Marija Prpić Nikolčina, Francikovac; Mladen Šojat Bilin, Francikovac.

110 Isti kazivači.

111 Isti kazivači.

112 Drugoga svjetskog rata.

113 Marija Prpić Nikolčina, Francikovac.

114 Anka Šolić Tutanova, Šolići.
} 
Nekad, prvo, tako je kod nas prvo bilo u selima više rodene djece 115 (iako se istovremeno ističe i veća smrtnost djece), kao i veća brojnost obitelji koje su živjele na području Krivoga Puta: K’o da se to znalo! Žena dok je bila sposobna radala je, a danas se djeca planiraju. A malo se di da ih je bilo manje, osim da žena nije bila sposobna za roditi ${ }^{116}$.

Krajem 19. i početkom 20. stoljeća prisutan je bio velik broj rođene djece unutar jedne obitelji ${ }^{117}$. Veći broj djece, u odnosu na narednu generaciju i danas, bio je, prema kazivanjima kazivača, još do sredine 20 stoljeća, uobičajen u obiteljima na području Krivoga Puta: Sve su tada imale. Neko 10, neko 12, neko $5^{118}$. Ne'ko je ima' osmero, ne'ko devetoro, al' nije ih bilo ispod četvero. Kod Luke ih je bilo 16 i njegov ćaća se dvaput ženio (smije se), a i kod Milana ih je bilo 18-tero. Ispod 8 je malo bilo ${ }^{119}$.

Isti kazivači, rođeni dvadesetih i tridesetih godina 20. stoljeća, uglavnom imaju dvoje ili troje djece, što pokazuje smanjenje broja rođene djece u smjeni samo jedne generacije. Razloge takvoj velikoj promjeni u broju rođene djece kazivači interpretiraju prije svega kao odraz vlastitih nastojanja da djeci pruže socijalnu sigurnost u vidu prehranjivanja, te osnovnog i (rjeđe) srednjoškolskog i stručnog obrazovanja. U skladu s predodžbom o vlastitim materijalnim mogućnostima neki su svjesno racionalizirali broj djece: $D a$ šta su, nego po sedmero, osmero, desetoro, po četrnaestoro! Posli su ljudi, vidilo, nije posla bilo, onda su mladi bili pametniji - šta će stvarat sirotinju kad nema kuda ni sobom ${ }^{120}$.

Milan Krmpotić Zekonja iz Veljuna zanimljivo pojašnjava zašto je imao samo troje djece, dok je njih braće i sestara bilo šesnaestoro: Oooo, bilo nas je čuda, osmero mrtvih i osmero živih. Šesnaest ih je majka moja imala, tri puta po dvoje. trinaest puta rodit, a šesnaestoro dice! (smije se) Nije to zgodno hranit bilo, puno djece, a ja sam mora bit na poslu, a ona, to je već bilo, baba nam je došla. Poslije bi majka (žena njegova) volila, al ne moreš ti, od posla i malo novaca, a imali smo i blaga puno, stoka je (...) uvijek se držalo to... Ne možeš puno dice, kako ćešs šnjim...

Također, zanimljivo tumačenje razloga namjernoj racionalizaciji broja djece je ono Milana Prpića Markinog iz Veljuna, koje ukazuje na povezanost materijalnih mogućnosti i promjena vrijednosti u društvu s obzirom na to što djetetu treba pružiti: Takav je tada običaj bio. Nije ga bilo tada sramota vidjet ni gola, ni bosa, moraš ih samo hranit. A već kad sam ja doša se to gledalo. E, a tek danas. A onda je to bilo: śta je koga bilo briga kol'ko će dice imat. Onda su i ljudi bili nepismeni, a poslije i danas je drukčije. Milanovi roditelji imali su šesnaestoro, a on ima dvoje djece (dva sina). Nadalje, Milan Zekonja iz Veljuna pojašnjava kako nije imao više od troje djece zato što je djecu trebalo školovati, a to je značilo racionalizaciju broja djece u korist osiguravanja kvalitete materijalne i socijalne sigurnosti djeci od strane roditelja: A kud ćemo? Dosta je i njih troje. I njih troje je 30 godina trebalo školovat. Ovaj sto je gluhonijem, osam godina je on u Zagrebu iša u školu, to je trebalo svaki misec platit, ček dolazi, nije ka i sada, sad plaćaju, i četiri godine poslije u Rijeci. Milanovi roditelji imali su jedanaestoro, dok on ima troje djece (dva sina i kćer). Marko Pavelić Vranićev iz Pavelića ima samo jednog sina, jer, kaže, slabe su prilike bile kada je sin krenuo u školu (šezdesetih godina 20. stoljeća).

Potrebe prehranjivanja i školovanja često se ističu kao ključan element pri odluci o racionalizaciji broja djece; Milan Cvitković iz Katića navodi kako se broj rođene djece znatno smanjivao od vremena kada su (tridesetih godina 20. stoljeća) rođeni on i žena. Navodi konkretan primjer iz ženina rodnog

115 Kroz razgovor je utvrđeno da se kazivanja o tome kako je bilo prvo, odnose na vrijeme koje kazivači poznaju prema pričama starijih, najčešće roditelja ili baka i djedova, a proteže se od početka 20. stoljeća, prije Drugog svjetskog rata, do sredine 20. stoljeća.

116 Zlata Tomljanović Pešina, Krivi Put.

117 To je podatak iz kazivanja kazivača rođenih tridesetih godina 20. stoljeća, prema vlastitom sjećanju i sjećanju na roditeljske priče: desetoro (Milka Prpić Markin(a)a, Veljun), petnaestoro, pa čak i šesnaestoro (Milan Prpić Zekonja, Veljun) djece.

118 Anka Prpić Burićeva, Krivi Put.

119 Milan Krmpotić Zekonja, Veljun.

120 Anka Prpić Burićeva, Krivi Put. 
mjesta Sevdara: Za moga vremena, od moje žene, bilo je njih više, tamo od njene majke mjesto, iz Sevdara, iza ovoga brda gore. Njih je bilo osamnaest, ali je samo dvije sestre, sve ostali muški. Tak je bilo većinom, malo ih je bilo da je bilo dvoje, troje, većinom šestero, sedmero, desetoro, petnaestero, to je bilo dice... Al prije ljudi nisu ni radili, nisu imali ni staža, to je sve živilo od poljoprivrede, ako bi nešto blaga, konje, vole, krumpira, žita i onda se to prodavalo. To je bila zadruga dole, tu di je crkva. ${ }^{121}$ To je bila zadruga i onda se to prodavalo i dobije koji dinar i plati porez $i$ tako. Preživljavali su za sebe. Kao razlog smanjenom broju djece navodi svoja razmišljanja istovjetna onima ranije spomenutih kazivača. Promjene društvenih vrijednosti i odnosa u pogledu odgajanja i školovanja djece, a time i veći materijalni izdaci, glavnim su razlogom namjernog smanjenja broja djece: Ne morete više ni imat. Nekad se i nije gledalo tude, vi kad ste išli tu u školu. Tu treba knjiga sad i treba svega, a prije kad sam ja iša' onda je bila samo jedna teka i pločica. Ima si pločicu i ako si pogriješija, obrisa si pločicu. Danas je drukčije, ako ti nemaš, otkuda dinara? To da platiš dom u Zagrebu ili Rijeci? To su veliki izdaci. Treba školovat.

Od sedamdesetih godina 20. stoljeća, zbog iseljavanja s područja Krivoga Puta (iz ekonomskih razloga) u selima ostaje starije stanovništvo: Tu smo sad samo mi starci. Svaki od tih mladih, tamo je posa, dite drago, slabi su to životi ovdje za mlade ljude, di će radit? ${ }^{122}$

\section{MEĐUGENERACIJSKA POMOĆ}

$\mathrm{D}$ o sedamdesetih godina 20. stoljeća u obiteljskoj bi kući ostajao živjeti tek jedan od braće. To nije nužno morao biti najstariji sin. Braća i sestre bi se iseljavali onim redom kojim su se ženili i udavali. Zadnji neoženjeni bi ostajao u obiteljskoj kući, a po običaju bi istovremeno dobio ulogu onoga koji će se pobrinuti za starčenje, odnosno, uzdržavati roditelje do kraja njihova života.

Iako u razgovoru kazivači direktno ne povezuju brigu o roditeljima s naslijeđivanjem obiteljske kuće, čini se kako je reciprocitet pruženog i dobivenog ipak na taj način u svim slučajevima bio uspostavljen. Drugim riječima, oni koji su ostali u obiteljskoj kući i uzdržavali roditelje, naslijedili su obiteljsku kuću, dok su se ostala braća svojeg dijela sporazumno odrekla. Milan Prpić Markin iz Veljuna je, primjerice, ostao zadnji od braće i sestara u obiteljskoj kući te objašnjava: Da, ovo su sve drugi išli, što se kaže, trbuhom za kruhom. Onaj je odša, odselija se tamo, onaj je odša, oženija se tamo, a otac i mater ostarili, nisu mogli nikud. Kada govore o brizi za roditelje, kazivači to poimaju kao vlastitu dužnost, ne dovodeći u pitanje nužnost zbrinjavanja roditelja, iako vrlo često žale zbog ostanka na području Krivog Puta, smatrajući iseljenje u druga područja boljom, neostvarenom, životnom i radnom perspektivom. U tom smislu, međugeneracijska pomoć mladih prema starijima, predstavlja društvenu vrijednost koju članovi obiteljske i društvene zajednice često neupitno prihvaćaju, a koja znatno određuje obiteljski život. U narednom odlomku bit će više riječi o tome kako su žene, supruge, preuzimale brigu o muževim roditeljima, doselivši nakon udaje u njihovu kuću.

Tomo Špalj Cucin prisjeća se kako je roditeljima bilo jako žao da to oni, a to je druga doba bilo, je žao da nije bilo muške djece, jer je bila i ona riječ: „Teško vatri po liskovoj grani i punici po zetovoj hrani“. Kćer gotovo uvijek nakon udaje odlazi u drugo kućanstvo, udaljeno od kućanstva svojih roditelja katkad i više od desetak kilometara (kada je riječ o drugom lokalitetu) ili dalje. Stoga je nemoguće da ona vodi brigu o svojim roditeljima. Tu ulogu, koja prati žensku liniju, kao i ostali poslovi vezani uz kuću, brigu o djeci, preuzima nevjesta koja dolazi u kuću svekra i svekrve.

Zlata Tomljanović Pešina je do sedamdesetih godina 20. stoljeća živjela u Krivome Putu, a zajedno sa suprugom i sinovima gradila je kuću u Senju, gdje su se konačno preselili. Danas stanuje u Senju, u prizemnom dijelu kuće. Jedan njezin sin, sa svojom obitelji, ženom i djecom, živi na prvom katu, a drugi sin na drugom katu. Odnosi funkcioniraju, kako Zlata kaže, dobro, bez sukoba. Ona katkad kuha sebi,

121 Misli se na Poljoprivrednu zadrugu Krivi Put, koja je osnovana nakon Drugog svjetskog rata, op. a.

122 Milan Prpić Markin, Veljun. 
a katkad joj ručak skuha jedna od dviju snaha. U svakodnevnom je kontaktu s mladima, što joj stvara određeni osjećaj sigurnosti, kako sama opisuje: Uvijek je tu netko da se pobrine za mene. I ja sam njima tu. Koliko je briga roditelja prisutna prema mladima s eksplicitnim ciljem da im se olakša i pomogne u svakodnevnom životu, slikovito nam dočarava iskaz Pavle Pavelić Vidine, majke, svekrve i bake: Ja sama sebi kuham, a njima (sinu, snahi i unucima) pomognem blago pričuvat i tako štogod, dok mogu, koliko im pomognem. Ona (snaha) ima dosta, i dice dvoje u školu slati i muža i svoga posla i uvik ima dosta posla. Treba svakoga razumit.

Većina kazivača svojoj je djeci pružila mogućnost školovanja koju, ističu, sami nisu imali s obzirom na financijsku situaciju njihovih roditelja. Marko Pavelić Mijatin(a) je, primjerice, dva desetljeća radio kao šumski radnik i mjesecima je bio odsutan od kuće kako bi, kako ističe, obitelji pružio dostojan život, odnosno, djeci omogućio daljnje školovanje. Svo petoro njegove djece, nakon završene zanatske škole, odselili su iz Žuljevića. Nije im htio, kako objašnjava, nametati svoju volju kako bi ostali na obiteljskom imanju. Danas žive u Senju i Rijeci, ali ga redovito posjećuju i pomažu mu u poslovima u kući. Ovaj primjer nije jedini. Uzajamna međugeneracijska pomoć prisutna je, u većoj ili manjoj mjeri, u svakoj obitelji. Djeca osjećaju obvezu pobrinuti se za roditelje, što kao vrijednost, u velikoj mjeri postavlja lokalna, društvena zajednica. Izostanak pomoći prema starijima određuje se, primjerice, riječima: To je bila sramota velika. $^{123}$

Prihodi od države prema starijim osobama, u vidu mirovina, danas najčešće iznose sedamstotina kuna. Stoga su vrlo često djeca u radnom odnosu te dodatni honorarni poslovi, ili privatno skromno vrtlarstvo, nužan dodatni izvor prihoda. U tom smislu, prema jednom kazivaču, ni danas odnos roditelj - dijete nije doživio velike promjene. ${ }^{124}$

Međugeneracijska pomoć uvelike je prisutna u slučajevima kada drugi izvori pomoći, (primjerice državna skrb i druga novčana sredstva) izostaju. Taj odnos reciprociteta je stalno prisutan, premda nijedan kazivač nije eksplicitno govorio o tome kako je njihova pomoć djeci povezana s očekivanjima da će djeca pravovremeno brinuti i za njih. Generacijama se, kroz odgoj unutar obitelji, s druge strane, unutar zajednice prenose i društvene vrijednosti poput onih iskazanih kazivanjem: Je obaveza bila; nije to bilo u pitanju stariji član on je bio kao takozvani gospodar on se je pita najviše i njega se i sluśalo a i u starosti i nemoći njega se $i$ dohranilo nije to da si ga ostavio, obveza djeteta prema roditelju nije upitna. ${ }^{125}$

Većina ispitanih kazivača stalno živi u gradu Senju, u koji su doselili mahom tijekom sedamdesetih godina 20. stoljeća, kada su se intenzivno odvijale migracije s Krivoga Puta u Senj. Kao jedan od razloga preseljenja mnogi navode i školovanje djece i pomoć mlađima. Ipak, rijetki su si školovanje u gradu doista mogli priuštiti: Slabe su prilike bile. On kada je krenuo u školu onda je sam bio odavde, samo je on bio, nikoga više, on je 1960. godište. ${ }^{126}$ Zlata Tomljanović Pešina, primjerice, preselila je u Senj iz razloga što je njezina snaha rodila blizance i njezina je pomoć snahi u tom trenutku bila nužno potrebna. Nakon toga Zlata ostaje trajno živjeti u Senju.

Pomoć starijih mlađima najčešće dolazi u vidu skrbi o maloj djeci (unucima). Potreba i praksa pružanja tog oblika pomoći najčešće se s obje strane ne dovodi u pitanje. Poima se, kako od strane mladih, tako i od strane starijih, kao nužnost i kao dužnost, prije svega emocionalna i moralna. Primjerice, Pavla Pavelić Vidina iz Veljuna živi u kući pored sina i snahe. Pavla je čuvala dvojicu unuka tijekom njihove predškolske dobi. Od šezdesetih godina do danas Pavla čuva blago na paši i brine oko njega u štali: Nešto napravim, pomognem i to. Blago, nešto u štali, sijeno, hranim $i$ tako. Bavi se i ručnom izradom metli, što objašnjava na sljedeći način: Ja to malo da ne kupujemo, jer kupimo, dademo 30 kuna i dva puta počistimo štalu $i$ ona

\footnotetext{
23 Marija Prpić Nikolčina, Francikovac.

124 Mladen Šojat Bilin, Francikovac.

125 Isti kazivač.

126 Marko Pavelić Vranićev, Pavići.
} 
se razvali. A ova dura po tri miseca, povežem žicom i dobro. Sve navedeno primjer je radnog i materijalnog doprinosa starije generacije mlađoj, unutar obitelji.

Zanimljiv segment međugeneracijske pomoći unutar rodbine predstavlja pojava usvajanja djeteta. Takvi slučajevi zabilježeni su na lokalitetima Šolići ${ }^{127}$ i Krivi Put ${ }^{128}$.

Kazivačica iz Veljuna, primjerice, dana je na usvajanje majčinim roditeljima, djedu i baki, s kojima je živjela do njihove smrti i svoje 27 godine. Njezina majka potom se udala jer, kako kaže: nije htjela za čovika ić s kojim je mene imala... O proporcionalnom odnosu davanja i primanja od obitelji danas govori: Kad sam bila mala, mama me je rodila i ostavila djedu i baki i udala se, a ja, kad su djed i baka umrli, ja sam ostala sama. Tako, poslije više nisam mogla živjet sama, otišla sam dalje. Trbuhom za kruhom. Oni su usvojili mene, ja sam dohranila njih i dobro.

Nadalje, kazivačica iz Krivog Puta navodi kako se njezina majka, rodom iz Matića, nakon smrti prvog muža, iz Šojatskog Dolca udala u Krivi Put zato što nije imala nigdi, nije bilo dinara, nije bilo novaca pa je mislila da će joj biti bolje ${ }^{129}$. Potom je, uslijed neimaštine, majka svoje dvije kćeri dala na usvajanje. Jednu kćer je usvojio njezin brat, djetetov ujak, koji sa svojom ženom nije mogao imati djece. Drugu kćer majka je ostavila u kući s djedom i bakom, svojim roditeljima. Kazivačica smatra majčinu odluku razumnom jer kaže: Oni su bili sami $i$ zašto bi nju vodila gore, a ona (majka) je ovdje nas imala šestero sa drugim mužem, mojim ocem. To je bio običaj, al' nije bilo sredstava k’o danas. Ne'ko bi uzeo tude ako nije imao, ali obično su svi imali (djece) pa nitko nije uzimao.



Slika 3: Tri generacije obitelji Ivana Prpića iz. Krivog Puta, oko 1930. (foto Arbiv GMS)

\section{RAD IZVAN KUĆE I U KUĆI - MUŠKII ŽENSKI POSLOVI}

$\mathrm{M}$ uškarci su, nakon ženidbe, bili oni koji su financijski privređivali za obitelj. Njihov rad je u svim ispitanim obiteljima bio izmješten iz mjesta stanovanja, bilo da se radi na manjoj (rad u šumi na području Krivog Puta) ili većoj (rad na cestama u drugim regionalnim područjima Hrvatske ili područjima ostalih republika bivše SFR Jugoslavije) udaljenosti od mjesta stanovanja.

\footnotetext{
127 Pavla Pavelić Vidina, Veljun.

128 Zlata Tomljanović Pešina, Krivi Put.

129 Ista kazivačica.
} 
Do sedamdesetih godina 20. stoljeća muškarci su radili pretežito u šumi ili na izgradnji cesta te je njihovo izbivanje od kuće moglo trajati mjesecima: Ja sam radija u Rijeci, po tri, četiri mjeseca nisam kući dolazija, nije se moglo. Nema, to ti je radno misto. Znao sam i doć kući, a popodne moram nazad ${ }^{130}$. Podjela na muške i ženske poslove postojala je u svijesti kazivača, kako u prošlosti, tako i danas. Na rad u šumi, ili na izgradnji cesta, odlazili su isključivo muškarci, a ti su poslovi na području Krivog Puta bili i najčešći način zapošljavanja muškaraca prije i nakon Drugog svjetskog rata te do sedamdesetih godina 20. stoljeća. Svakodnevni posao oko blaga, u polju i oko kuće, smatrao se također muškim poslom. Međutim, istraživanjem je zabilježeno kako su žene ne samo sudjelovale u takvim poslovima, iako ih i same smatraju muškima, već su ih obavljale same ili uz minimalnu pomoć muških članova. Razlog tomu najčešće je bila suprugova višemjesečna odsutnost od kuće, zbog rada u šumi ili na izgradnji cesta. Kazivanjima o različitim obiteljskim okolnostima uočeno je da su žene, nakon udaje, došavši u kuću suprugovih roditelja i u dnevnoj odsutnosti muževa, preuzimale najveći dio poslova u kući i oko nje, kao i brigu o djeci i o suprugovim roditeljima. Milan Prpić Markin iz Veljuna eksplicitno je, u prisutnosti žene, istaknuo potrebu za ženskim radom i brigom oko njegove majke kao relevantan razlog ženidbe, kada je Milan, s 23 godine, već bio zaposlen: Ne bi se ja ni bija ženija, al kad je mater sama bila... Stara, k’o sad ja i ona (supruga), a ja sam delal, jadan, kud cu, ako odem ča, "ko će im pomoć? Devet godina je majka bila bolesna u krevetu, nepokretna, ona nije mogla od nje (pokazuje na suprugu)... Milan Krmpotić Zekonja iz Veljuna također je istaknuo kako je njegova žena preuzela brigu o njegovim roditeljima: Više se žena brinula nego ja, kad sam ja po poslu bio. Ona je onda š njima, dakako. Više ona nego ja. To se poštivalo starčenje.

\section{SUŽIVOT DVIJU NUKLEARNIH OBITELJI}

Z animljiv dio obiteljskih odnosa, zabilježen tijekom istraživanja na području Krivoga Puta, predstavlja suživot dviju nuklearnih obitelji, dvojice braće sa ženom i djecom, u roditeljskoj, kući. Potvrde o takvom suživotu dobivene su za mjesta Francikovac i Veljun ${ }^{131}$, kao oblik privremene ili stalno (no, bez eksplicitne namjere) proširene obitelji, ovisno o materijalnim prilikama. Ovaj se oblik stanovanja odvijao bez zajedničkog privređivanja i kuhanja, sa stalno prisutnom tendencijom zasnivanja samostalnog kućanstva, odnosno, iseljenjem jedne od dviju nuklearnih obitelji. ${ }^{132}$ Pritom naglasak stavljamo na privremenost i/ili tendenciju privremenosti, te na segment odvojenog privređivanja i kuhanja, kao temeljne značajke ovog suživota, a takav oblik ne predstavlja zadružni oblik obiteljskog života i stanovanja, kakav je osamdesetih godina 20. stoljeća zabilježila M. Černelić.

Milka Prpić Markina je istaknula kako su njezin otac i stric do kraja života živjeli u istoj kući u Veljunu, sa ženama i djecom: Ima, ima i tog. Pa i tu su bili dupli u kući. Moj stric i moj tata. U istoj kući. Teško se živjelo, nemaš kud.

Marija Prpić Nikolčina iz Francikovca je također na konkretnom primjeru pojasnila postojanje suživota obitelji dvojice braće pod jednim krovom u Francikovu, te, zanimljivo je, ističe, vrlo skladan odnos dviju jetrvi, što kazivači nerijetko negiraju, a o čemu će biti više govora dalje u tekstu: Svekrva i njih su dva brata bila. Ona je i to su jetrve, od dva brata žene, one su bile jedno 40 godina skupa nikad se nisu svadale $i$ poslije kada se ova odselila u Senj, strina Marinka, ona je kad je odlazila u Senj, ona je, moja svekrva, imala sestru, ali se radije navraćala kod svoje jetrve, nego kod sestre; jer ona je više života provela sa svojom jetrvom nego sa sestrom. Zato jer od ove jedne je muž poginija u šumi, od ove Marinke, a da je on bio živ onda bi se sigurno podijelili.

$\overline{130}$ Milan Prpić Markin, Veljun; Milan Krmpotić Zekonja, Veljun; Marija Prpić Nikolčina, Francikovac; Milka Prpić Markina, Veljun.

131 Milan Krmpotić Zekonja, Veljun.

132 Narednim istraživanjima trebalo bi pojavu i jasnije vremenski precizirati te utvrditi je li riječ o raširenijoj pojavi, na kojim sve područjima Krivoga Puta te u kojem je obliku (primjerice, s ili bez zajedničkog privređivanja) postojala. 
Kazivači redovito ističu kako su na suživot pod jednim krovom braća bila prisiljena zbog neimaštine i nemogućnosti da se jedan od njih (s obitelji) iseli u drugu kuću, drugo naseje, ili čak drugo područje $\mathrm{Hr}$ vatske, gdje bi otpočeo samostalan život. Takav suživot naročito je bio prisutan u međuratnom razdoblju i nakon Drugog svjetskog rata, u razdobljima velike neimaštine, te nakon pravne regulacije i naredbe o diobama zadruga. ${ }^{133}$

Iseljavanje braće iz obiteljske kuće često bi se rješavalo priženjivanjem, odnosno, preseljenjem muškarca (supruga) u nevistinu roditeljsku kuću. Na području Krivoga Puta nije zabilježeno kazivanje ili stav o tome kako je odlazak mladoženje u kuću mladinih roditelja bio sramotan čin. Dapače, Krivopućani ga smatraju jednim od razumnih rješenja skućivanja. Ipak, ističu i kako je dolazak mladoženje u mladenkinu obiteljsku kuću zastupljen u daleko manjoj mjeri nego obrnuto. ${ }^{134}$ To se događalo najčešće u slučajevima kada nevista nema braće, već sestre za koje se pretpostavlja da će otići živjeti k mladoženjinim roditeljima.

U međuratnom su razdoblju kućanstva bila pretežno višegeneracijska, uglavnom rodbinski povezana. Mladen Šojat Bilin iz Francikovca navodi primjer takvog suživota na primjeru vlastite šire obitelji: Živija je sin, osta' sa ocom i majkom i babom i djedom. Pa čak i pradjed, četiri su znale biti, od neviste djece do svekra i svekrve unučad, prapradjed. Ja kad sam se rodija onda je moj pradjed bio živ.

O mnogobrojnosti članova govori i kazivanje o često korištenom lokalnom izrazu: Moja svekrva kada je došla ovdje onda su samo pričali da je za trinaestu žlicu uhvatila, što uznači da je trinaesta bila u kuću došla. ${ }^{135}$

Jedno vrijeme braća su živjela zajedno, dok nisu načelnim, usmenim, dogovorom podijelili imovinu, bez iseljavanja jednog ili drugog brata s imanja: Sve se podijelilo i zemlja i kuća i blago i tako da su postali susjedi, a živjeli su dotad u istoj kući, u istoj prostoriji. Al nije bilo da su napravili novu kuću, nego u istoj prostoriji, kako je 'ko dobija, jednu, dvije prostorije, po velicini kako je bila koja familija. Ovdje je oduvijek bilo četiri, pet prostorija, to je drugo bilo, a bilo je di su braća podijelila sve, njih tri su brata bila u tri prostorije. Tu dolje na putu, špic-namet Pepicí. To je bilo od tridesetih godina, od dvadesete pa naprvo, ja znam generaciju; znam djecu od te braće. Onda su se oni poslije razišli, jedan je od njih onda poslije i napravio kuću. ${ }^{136}$

Nakon Drugog svjetskoga rata takav se suživot uglavnom potpuno napušta, jer se i na državnoj razini uvode mjere kreditiranja; industrijska proizvodnja i zapošljavanje u državnim tvornicama i poduzećima postupno rastu, a time i životni standard. ${ }^{137} \mathrm{~Pa}$ se i obiteljske kuće Krivopućana postupno proširuju i nadograđuju. Sve to utječe na napuštanje življenja dviju nuklearnih (roditeljski par sa djecom) obitelji u istoj kući, kao odraz materijalne nemogućnosti formiranja samostalnoga kućanstva.

Nakon godine dana zajedničkog življenja, jedna bi se obitelj iselila. Ipak, kako spominje Milan Prpić Markin iz Veljuna, bilo je slučajeva kada to nije bilo moguće. Spomenuo je primjer oca i strica koji su u istoj kući (nakon Prvog svjetskog rata) živjeli do kraja života, što je bio rezultat neimaštine: $M a$, do smrti su zajedno bili u toj kući. Ima je svako svoju sobu tamo... Nije to bilo lako, za rata prvog, kako si moga radija si. A sada 'ko ima puno djece - i država ga pomaže. A koga će onda država pomagat?

Pavla Pavelić Vidina koja je rodom iz Veljuna, a živi u Šolićima, s druge strane osobno ne pamti viđene slučajeve da su braća živjela zajedno u jednoj kući, a i ističe sveprisutnu tendenciju što ranijeg razdvajanja i osamostaljenja mladih. Prema pričama starijih, suživot dvojice braće s obiteljima u jednoj kući smješta

133 Zakonska regulativa u Kraljevini Hrvatskoj i Slavoniji; nastajanje novih kućanstava omogućeno je Temeljnim zakonom za Vojnu krajinu iz 1807. godine u kojem se to, pod propisanim uvjetima, omogućava (Pavličević 1989:274279).

134 Pavla Pavelić Vidina, Veljun; Milan Prpić Markin, Veljun.

135 Mladen Šojat Bilin, Francikovac.

136 Isti kazivač.

137 Pavla Pavelić Vidina, Veljun; Milan Krmpotić Zekonja, Veljun. Mladen Šojat Bilin, Francikovac. 
u polovicu 19. stoljeća, a naglašava kako su tada, prema pričama starijih, pod istim krovom u tom slučaju živjeli i roditelji, svekar i svekrva, te kako je u takvom suživotu vladala sloga: Prije možda 150 godina dva brata su znala skupa živjet i dvije jetrve i svekrve i sve zajedno. I dica i svi. I svi bili u jednoj kući i svim bilo dobro. A danas ne more niko s nikim.

Prema vlastitom sjećanju, ista kazivačica napominje kako bi se u Veljunu braća razdvojila čim se jednom od njih ukaže (materijalna, stambena) prilika: To se vjenčaju, možda da su godinu dana i odma se podile. Pa makar je on ima jednu prostoriju, odma'se razidu. Podijele kuću i zemlju ili ode jedan dalje, ako ima kamo. Ide tražit boljeg života. Jedan ostane, jedan ode. ${ }^{138}$

\section{PODJELA OBITELJSKE IMOVINE}

Z načajan segment društvenog i obiteljskoga života Krivopućana je i podjela imovine. Već je spomenuto kako je siromaštvo bilo najčešćim razlogom iseljavanja s Krivoga Puta te kako na ovom području uglavnom i nije bilo izdašnije imovine koja bi se među mnogobrojnom djecom mogla dijeliti. Stoga se iseljavalo najčešće sporazumno, uz usmeno odricanje od ionako skromnog dijela obiteljske kuće, u korist onoga koji bi u obiteljskoj kući ostajao. ${ }^{139}$

Ukoliko bi pak dolazilo do diobe, one bi se nerijetko odvijale tajno. Kazivanja ipak svjedoče o tome kako je postojalo saznanje unutar lokalne zajednice o tome tko se, i na koji način, podijelio, čime se zapravo dovodi u pitanje tajnost tih diobi u praksi.

Ipak, ključna dimenzija tajnosti bila je sadržana u tome da se dioba ne obavi formalno, zakonski, već sporazumno i usmeno: Tajna je (dioba) zato što to zakon nije znao. To se radilo u svrhu izbjegavanja velikih troškova koje bi iziskivala formalna registriracija promjena.

U Francikovcu je zabilježen podatak o saznanjima tamošnjih lokalnih ljudi o tome tko je i na koji način izvršio tajnu diobu u selu. S tim u vezi zabilježen je i zanimljiv termin: lumeri, kojim se označavalo kuće, odnosno, obitelji koje u tim kućama žive, a lumeri su se brojali prema saznanjima o internim podjelama unutar obitelji. Primjerice, kazivač iz Francikovca spominje kako je u Francikovcu polovicom 20. stoljeća bilo 24 lumera, familije, a u razgovoru je kazivačica iz Francikovca pojasnila: Da, lumeri, kako bih rekla, kuće, imanja, a na što se kazivač nadovezao: Uvijek su računali: 21 lumer je u Francikovcu, 21 obitelj.

$\mathrm{Na}$ pitanje kako se računalo ako su u kući živjela dva brata, kazivač je spomenuo kako su to bile dvije obitelji: Ako su se podijelili, a za to nije zakon znao, to su bile tajne diobe i nisi smio reć. Zanimljiva su konkretna kazivanja o pojedinačnim slučajevima takvih podjela, kojima se pokazuje da su lokalna znanja o podjelama unutar obitelji u selu bila više nego prisutna, koja smo odznali od jednog kazivača: Kod Savića njih je bilo sedam, a njih su dva brata se podijelili, Nikola i Joso, Kurtići i Cupicí, isto su dva brata, tu je bilo nekada, kad je bilo više djece, al' kad su se dva brata podijelila onda je sedam kuća nastalo. U moje selo je dośa Šojat i od njega smo mi, moji preci, ima to već 400 godina kad su se doselili, jedan je otiša u Šojatski Dolac. I od ta dva smo mi sedamnaest kuća, mi Šojati, smo nastali, moja obitelj, tako da smo krvno svi vezani. Za te diobe znalo se u familiji. Na to je kazivačica nadodala: A znalo se i u selu.

Postupak dogovaranja oko podjele opisan je na sljedeći način: Nije se tražio katastar, ni geometar da on to podijeli, zakonski svak je svoje uknjižio i katastarski oni su proveli tajnu diobu, ali su poslije i uknjižili da imaju sve dokumente. Oni su se dogovarali kad su došli na komad, kome će lijeva, kome će desna strana, nisu htjeli da na ovome predjelu jedan njemu, jedan meni, nego svaki komad popola, ali to se uvijek računalo da je ovdje možda bolja zemlja nego tamo... Svaki komadićse dijelija, tamo je parcela tebi, Marko, tamo tebi. Svaki komad se dijelio po braći. Ako je bilo više, na dva, i tako se dijelilo.

138 Kazivačica nije znala jesu li takve obitelji poznavale zajedničko privređivanje, na koji način se dijelila njihova imovina, odnosno, da li bi takve obitelji mogle biti interpretirane kao zadružne. Valjalo bi narednim istraživanjem konkretizirati i pojasniti strukturu više obitelji prema različitim kazivanjima te utvrditi najvjerojatnije paralelno postojanje više zanimljivih, raztličitih oblika obitelji na jednom prostoru u određenom, istom vremenskom okviru.

139 Onaj koji bi u kući ostajao, uzdržavao bi roditelje. 
Kazivačica također opisuje postupak dijeljenja, ali pritom ističe mogućnost nepravednih podjela, što je dovodilo do neslaganja unutar obitelji: Oni su se dilili i onda će ovaj stariji, to će meni, a ovo tebi i onda opet drugi komad ovaj stariji, ovo meni, ovo tebi. A on sebi daje bolju zemlju, a ovaj mladi veli: Bog vidi! I tako stalno. Nije svuda bilo baš ono fer. Mladen Šojat Bilin je istaknuo kako je presudna bila dominacija autoriteta starijeg brata te je Joso, stariji, on je dilio i veli: Brate Antonu, ovo meni, ovo tebi, ovaj komad popola. A on je sebi uvijek bolju zemlju... Tako su se dijelili. Nije samo to. I drugi su se tako dijelili, tako su se i Savići dijelili. Stariji je brat uzeo bolji komad.

Budućim bi istraživanjem trebalo vremenski precizirati dobivene podatke, utvrditi je li možebitno riječ o nekadašnjoj diobi zadruga te utvrditi sličnosti i razlike vezane uz nasljeđivanje imovine između zadružnog i ostalih oblika obitelji.

\section{POTENCIJALNI SUKOBI: I NJIHOV SE VEŠ NA ŠTRIKU SVAĐA!}

Cukobi i neslaganja su, prema svim kazivačimaa, tijekom 20. stoljeća najčešće izbijali na sljedećim srod$\checkmark$ ničkim razinama: između dviju jetrvi ${ }^{140}$, između snahe i svekrve, između neviste i mladoženje spram svekra i svekrve, ili tasta i punice, te između braće i sestara (najčešće u u kontekstu podjele imovine).

Loš odnos dviju jetrvi, često istican u kazivanjima ispitanog stanovništva, odnosi se na neslaganja prilikom spomenutog življenja u istoj kući, pod jednim krovom, bez zajedničkog privređivanja i kuhanja, te $s$, primjerice, odvojenim prostorom za kuhanje i spavanje, kako bi se mogućnost dnevnog neslaganja svela na najmanju moguću mjeru. Ipak, zabilježen je i podatak, mada nepreciziran, o većem slaganju članova obitelji u prošlosti, što bi narednim istraživanjem trebalo precizirati, vremenski jasnije odrediti te uvidjeti o kojem obliku suživota je riječ: Pa, prvo je to bilo, dite moje, stari naši, moji. Djed i baka pričali, to su znale bit po dve, tri jetrve skupa. Prije valjda 200 godina, Bog zna, a danas valjda ne more ni dva brata, još nisu ni, još u školu iđu, a ovaj grabi sebi i ovaj sebi. Nije to više to ${ }^{141}$.

Tijekom prve polovice 20. stoljeća često su, kako je spomenuto, prostor jedne kuće koristile dvije nuklearne obitelji, od dvojice braće. Iako su dijelili jednu zajedničku, veću prostoriju, u kojoj se kuhalo, žene u obitelji, supruge - jetrve, nerijetko su kuhale odvojeno i u kući su postojala dva otvorena ognjišta. Neslaganje između dviju jetrvi kazivači najčešće pripisuju ženskoj naravi: Braća nigdje nisu da su bila zajedno dugo. Dok se ne požene jesu, a poslije ne. Ne slažu se više jetrve. Tako, da, tako je to priroda dala ${ }^{142}$. Njegov otac i stric su sa svojim obiteljima jedno vrijeme živjeli u istoj obiteljskoj kući. S vremenom je stric na obiteljskom imanju izgradio zaseban dio, oni su se podijelili i svaki je za sebe bija. U takvoj situaciji dolazilo je i do sukoba i neslaganja, a lokalno stanovništvo potencijalne ili ostvarene sukobe u obitelji unutar jednog kućanstva najčešće pripisuje lošem odnosu između dviju jetrvi, navodeći pritom često spominjanu uzrečicu: I njihov se veš na striku svada!

Odnosi između svekrve i neviste također se često opisuju kao mjesta mogućih i često prisutnih sukoba. Primjerice, Pavla Pavelić iz Šolića, koja je živjela sa svekrvom, govori kako je njihov odnos bio čak relativno dobar, bez čestih nesuglasica, iako, prisjeća se: Kako kad, ka i svaka svekrva i nevista. Kažu, kad nisi skupa, onda ste bolji, a kad jeste skupa, onda niste dobri.

Ipak, razlozi potencijalnom neslaganju dviju nuklearnih obitelji ili dviju jetrvi, smatramo, nisu prirodno, kako to implicitno kazivači podcrtavaju, već društveno i kulturno uvjetovani. Obje mlade obitelji, bilo da je riječ o manjem ili većem stupnju (ne)slaganja, teže za uspostavljanjem vlastitog životnog prostora čim im se za to pruži prilika pa se braća najčešće razilaze, prema kazivanjima, nakon otprilike godine dana zajedničkog življenja, ako, u međuvremenu, jedan od njih za svoju obitelj pronađe drugo stambeno

\footnotetext{
${ }_{140}$ Zabilježen i istaknut u kazivanjima ispitanog stanovništva, a odnosi se na neslaganja prilikom spomenutog življenja u istoj kući, pod jednim krovom, bez zajedničkog privređivanja i kuhanja, te s, primjerice, odvojenim prostorom za kuhanje i spavanje.

141 Pavla Pavelić Vidina, Veljun.

${ }^{142}$ Marko Pavelić Mijatin(a), Žuljevići.
} 
rješenje. Isto tako, razdvajanje prostora za pripremanje hrane, bio je, čini se, jednim od čestih načina da se sukobi u obitelji izbjegnu ili svedu na najmanju moguću mjeru. Kuhinja, kao tradicionalno ženski prostor, mjesto je u kući u koji žena (pod utjecajem društveno konstruiranih podjela i nepisane obveze prihvaćanja ženske uloge) upisuje svoja pravila i unosi iskustva i navike koje donosi iz obiteljskog doma. S obzirom da jetrve potječu iz različitih obitelji, mjesta, a često i različitih zemljopisnih područja, nije neobično što su sukobi mogli izbiti upravo oko poslova oko pripremanja hrane za obitelj, kao dnevnog i nužnog segmenta života unutar istog kućanstva.

\section{ZAKLJUČNA RAZMATRANJA}

P rilog predstavlja opis i analizu pojedinih, etnološki zanimljivih, tema obiteljskog života i odnosa na području Krivoga Puta, a koje se odnose ponajviše na vremensko razdoblje od tridesetih godina do sedamdesetih godina 20. stoljeća (djelomično i do današnjih dana). Sve su teme istražene terenskim istraživanjem 2006. godine.

Prvi, teorijski dio priloga donosi nekoliko problemskih pitanja vezanih uz etnološko istraživanje obitelji, te naznačuje moguće tematske smjernice za daljnja istraživanja. Istraživanjem je bilo obuhvaćeno nekoliko podtematskih cjelina, sagledanih kroz kazivanja i interpretaciju lokalnog stanovništva, rođenog većinom dvadesetih i tridesetih godina 20. stoljeća, koje čine etnološki zanimljiv dio obiteljskih odnosa, vrijednosti i praksi: rodbinski nazivi, brojnost djece, iseljavanje radno sposobnog, mladog stanovništva u gradove, siromaštvo u prošlosti i implikacije na obiteljski život, rad u kući i izvan kuće, suživot dviju nuklearnih obitelji u jednoj kući, raspodjela obiteljske imovine te potencijalni i ostvareni obiteljski sukobi. U istraživanju je težište stavljeno na promjenljivost obiteljskih prilika, odnosa i vrijednosti (društvene, obiteljske) koje svaka obitelj, i njezini članovi, podržavaju ili odbacuju, a koje uvelike određuju život pojedinca i obitelji. To su, primjerice: podjela na muške i ženske poslove, pravila pri nasljeđivanju imovine, briga o starijima i sl. Obrađeni tematski blok predstavlja polazište za daljnja istraživanja i jedan segment obiteljskog i društvenog života na području Krivog Puta, te nipošto ne obuhvaća sve teme koje na jednom zemljopisnom i kulturnom području mogu biti predmetom etnološkog istraživanja, u određenom vremenskom okviru. Obiteljski život i odnosi na području Krivoga Puta još uvijek nisu sustavno etnološki istraženi i temeljitije istraživanje tih odnosa tek predstoji.

Etnologija je, $s$ jedne strane pozvana istraživati (...) ono što se naziva „idealnim“ sustavima $i$ „apstrakcijama" pod uvjetom da se takvima i označe "143. S druge strane, komparativnim pristupom i metodom studija slučaja, etnološki treba istraživati različite svakodnevne prakse i pojedinačna iskustva obiteljskog života.

Podatci za područje Krivoga Puta svjedoče o preplitanju općeprihvaćenih društvenih vrijednosti, i pojedinačnih i obiteljskih razlika u praksi. Time doprinose sveobuhvatnijem, empirijski utemeljenom, uvidu o društveni i obiteljski život jednog regionalnog područja.

Sustavnih istraživanja obiteljskog života u hrvatskoj etnologiji nedostaje, pa bi tako trebalo nastaviti i $s$ istraživanjima na području Krivog Puta. Dosad prikupljeni podatci naznačuju smjernice budućim istraživanjima te predstavljaju doprinos poznavanju društvenog života krivoputskog područja u razdoblju koje prethodi intenzivnijem iseljavanju u gradove, depopulaciji i modernizaciji područja.

\section{LITERATURA I IZVORI:}

BOGOVIĆ, Mile (2008): Župa Krivi Put, u: Živjeti na Krivom Putu, sv. I (ur. Milana Černelić, Marijeta Rajković, Tihana Rubić), Sveučilište u Zagrebu, Filozofski fakultet, Odsjek za etnologiju i kulturnu antropologiju, FF-press i Gradski muzej Senj; Zagreb, 69-75.

143 Pleše 1998: 63. 
ČAPO ŽMEGAČ, Jasna (1996): Konstrukcija modela obitelji u Europi i povijest obitelji u Hrvatskoj. Narodna umjetnost, 33/2, Zagreb: 179-196.

ČAPO ŽMEGAČ, Jasna (1998): Seoska društvenost, u: ur. Vitomir Belaj (et. al.), Hrvatska etnografija, Svagdan i blagdan hrvatskog puka, Zagreb, 251-295.

ČAPO ŽMEGAČ, Jasna (1998): Elementi hrvatske seljačke kulture u prostoru i vremenu, u: ur. Vitomir Belaj (et. al.), Hrvatska etnografija, Svagdan i blagdan hrvatskog puka, Zagreb, 9-20.

ČAPO ŽMEGAČ, Jasna (2001), Od lokalne do nacionalne zajednice: seljačka društvena struktura, u: Hrvatska tradicijska kultura na razmeđu svjetova i epoha, Zorica Vitez i Aleksandra Muraj (ur.), Zagreb, 497-541.

ČERNELIĆ, Milana (1999): Zadruga Rukavina Jauci iz Smiljanskog Polja, Senjski zbornik, 26: 297-312, Senj.

ČERNELIĆ, Milana (2000): Dvije zadružne obitelji na području Krivoga Puta. Senjski zbornik, 27:199216, Senj.

ČERNELIĆ, Milana (2003): Istraživanje tradicijske baštine, identiteta i etnogeneze primorskih Bunjevaca. Senjski zbornik, 30, Senj: 407-424.

HAVILAND, William (2004): Kulturna antropologija, Naklada Slap, Zagreb.

LJUBOVIĆ, Blaženka (2007): Zemljopisni položaj i pregled novije povijesti Krivog Puta, u: Živjeti na Krivom Putu, sv. I (ur. Milana Černelić, Marijeta Rajković, Tihana Rubić), Sveučilište u Zagrebu, Filozofski fakultet, Odsjek za etnologiju i kulturnu antropologiju, FF-press i Gradski muzej Senj; Zagreb, 69-75.

PAVLIČEVIĆ, Dragutin (1989): Hrvatske kućne zadruge, Sveučilišna naklada Liber, Zavod za hrvatsku povijest Filozofskog fakulteta u Zagrebu, Zagreb.

PLEŠE, Iva (1998): Neki aspekti hrvatske terminologije srodstva, Etnološka tribina, 21, Zagreb: 59-78.

RAJKOVIĆ, Marijeta (2004): Prilozi poznavanju migracija Krivopućana, Senjski zbornik, 31, Senj: 261 286.

RAJKOVIĆ, Marijeta (2008): Pregled suvremenih migracija Krivopućana, u: Živjeti na Krivom Putu, sv. I (ur. Milana Černelić, Marijeta Rajković, Tihana Rubić), Sveučilište u Zagrebu, Filozofski fakultet, Odsjek za etnologiju i kulturnu antropologiju, FF-press i Gradski muzej Senj; Zagreb, 79-94.

RAJKOVIĆ, Marijeta (2008): Primorski Bunjevci Krivopućani na području Virovitice, u: Živjeti na Krivom Putu, sv. I (ur. Milana Černelić, Marijeta Rajković, Tihana Rubić), Sveučilište u Zagrebu, Filozofski fakultet, Odsjek za etnologiju i kulturnu antropologiju, FF-press i Gradski muzej Senj; Zagreb, 95-119.

RIHTMAN, Dunja (1967): Pokušaj pristupa izučavanju društvenih vrijednosti. Vrijednosti kao prisutna dimenzija u ponašanju i odlučivanju, Ekonomski fakultet, Zagreb.

RIHTMAN-AUGUŠTIN, Dunja (1984): Struktura tradicijskog mišljenja, Školska knjiga, Zagreb, 165 185.

RUBIĆ, Tihana (2008): Tradicijska trgovina i sajmovi, u: Živjeti na Krivom Putu, sv. I (ur. Milana Černelić, Marijeta Rajković, Tihana Rubić), Sveučilište u Zagrebu, Filozofski fakultet, Odsjek za etnologiju i kulturnu antropologiju, FF-press i Gradski muzej Senj; Zagreb, 323-352.

SARTI, Raffaella (2006): Živjeti u kući. Stanovanje, prehrana i odijevanje u novovjekovnoj Europi (1500.1800.), Ibis grafika, Zagreb.

SEGALEN, Martine (1997): Srodstveni odnosi u zapadnim (zapadnoeuropskim) društvima. Povijesne i suvremene perspektive, Etnološka tribina, 20, Zagreb:29-49.

Seljačke obiteljske zadruge, Izvorna grada za 19. i 20. st. (1960), Sv. 1, Etnološki zavod, Zagreb.

Seljačke obiteljske zadruge, Izvorna grada za 19. i 20. st. (1992), Sv. 2, Etnološki zavod, Zagreb.

Upitnice Etnološkog atlasa (UEA), svezak III, Fd 241/651, teme br.: 106. Vrste zadruga, osobina, dioba; 107. Rodaci i njihovo oslovljavanje; 108. Nekrvno srodstvo; 109. Selo kao zajednica; 110. Glavni oblici zajedničkog rada; 112. Podjela poslova po spolu; 113. Ženske svečanosti i povlastice; te 114: Znakovi 
vlasništva i zabrane, Arhiv Odsjeka za etnologiju i kulturnu antropologiju, Filozofski fakultet u Zagrebu.

VENE, Lea: Djetinjstvo i odrastanje u Podgorju: služenje i dječji rad, Senjski zbornik, 35, Senj: u tisku. 